\title{
What is the resource footprint of a computer science department? Place, people, and Pedagogy
}

\author{
I. S. Mian, D. Twisleton and D. A. Timm \\ Department of Computer Science, University College London, London, United Kingdom \\ *Corresponding author. Email: D.Timm@cs.ucl.ac.uk
}

Received: 03 December 2019; Revised: 19 June 2020; Accepted: 27 June 2020

Keywords: rejuvenate and (re)integrate the natural and built environments; rematerialising the information society; resourceconstrained computing, computation, and communication; responsible research and innovation; zero waste institution; environmental accounting; waste reduction; data centre management; IT infrastructure lifecycle; environmental policy

\begin{abstract}
Internet and Communication Technology/electrical and electronic equipment (ICT/EEE) form the bedrock of today's knowledge economy. This increasingly interconnected web of products, processes, services, and infrastructure is often invisible to the user, as are the resource costs behind them. This ecosystem of machine-to-machine and cyberphysical-system technologies has a myriad of (in)direct impacts on the lithosphere, biosphere, atmosphere, and hydrosphere. As key determinants of tomorrow's digital world, academic institutions are critical sites for exploring ways to mitigate and/or eliminate negative impacts. This Report is a self-deliberation provoked by the question How do we create more resilient and healthier computer science departments: living laboratories for teaching and learning about resource-constrained computing, computation, and communication? Our response for University College London (UCL) Computer Science is to reflect on how, when, and where resources - energy, (raw) materials including water, space, and time - are consumed by the building (place), its occupants (people), and their activities (pedagogy). This perspective and attendant first-of-its-kind assessment outlines a roadmap and proposes high-level principles to aid our efforts, describing challenges and difficulties hindering quantification of the Department's resource footprint. Qualitatively, we find a need to rematerialise the ICT/EEE ecosystem: to reveal the full costs of the seemingly intangible information society by interrogating the entire life history of paraphernalia from smartphones through servers to underground/undersea cables; another approach is demonstrating the corporeality of commonplace phrases and Natureinspired terms such as artificial intelligence, social media, Big Data, smart cities/farming, the Internet, the Cloud, and the Web. We sketch routes to realising three interlinked aims: cap annual power consumption and greenhouse gas emissions, become a zero waste institution, and rejuvenate and (re)integrate the natural and built environments.
\end{abstract}

\section{Policy Significance Statement}

We propose two maxims to aid policy making and the preparation of guidelines aimed at creating a more resilient and healthier Department of Computer Science UCL—dictums that, in conjunction with our roadmap, are of potential utility to analogous departments at other universities domestically, regionally, and internationally. The first general principle is that resource use needs to be both minimised and minimal: reduced in relative as well as absolute terms. The second is that responsible research and innovation entails not simply decreasing the resource footprint of a research facility, organisation, institution, or project but also considering nontechnological solutions to complex real-world problems in conjunction with the opportunity costs when the ICT/EEE ecosystem is the first port of call for answers. 


\section{Introduction}

The Fourth Industrial Revolution (4IR) encompasses a range of new technologies that are fusing the physical, digital, and biological worlds (Schwab, 2016). ${ }^{1}$ Discourse on this economic, industrial, and social paradigm ${ }^{2}$ is replete with phrases such as artificial intelligence (AI), machine learning (ML), the platform economy, automated/algorithmic decision-making, distributed ledger technology (DLT), advanced (bio)manufacturing, genetic codes, and biodiversity data. This is because at its heart lies the knowledge economy: a complicated interlaced mixture of digitisation, datafication, information, analytics, software, hardware, operations, and networks (World Economic Forum, 2017). Since digital technologies reshape the individuals and communities manufacturing and using them (Winner, 1980; Qiu, 2016; Eastwood et al., 2017; Hankey and Tuszynski, 2017), the multitudinous impacts of the ICT/EEE ecosystem, component wise and collectively, are subjects of increasing concern and scrutiny (Chatfield et al., 2017; Morozov, 2017; Stahl et al., 2017; Bandara and Carpenter, 2018; Crawford and Joler, 2018; Levine, 2018; McQuillan, 2018; Nardi et al., 2018; Bassey, 2019; Dãno and Prato, 2019; Donovan and Park, 2019; Howell, 2019; Kolinjivadi, 2019; Lohmann, 2019; Lohmann and Hildyard, 2019; Sadowski, 2019; Thomas, 2019; United Nations Conference on Trade and Development (UNCTAD), 2019). Issues include the fitness for purpose of competition/antitrust law in areas such as algorithmic pricing, collusion, compliance, climate change, and sustainability (Schwalbe, 2018; Autorité de la concurrence and German Bundeskartellamt, 2019; Calvano et al., 2019; Competition Authorities Working Group on Digital Economy, 2019; Conner, 2019; Deng, 2019; Lianos, 2019; Trade and Development Board, Trade and Development Commission, and Intergovernmental Group of Experts on Competition Law and Policy, 2019; Holmes, 2020), the transformation of data from objects to assets (Leonelli, 2019), frameworks for community data ownership (Singh and Vipra, 2019), intra- and intergenerational inequalities (Guttieres, 2019), tax-related provisions in rules on digital trade (James, 2019), developmental justice (Gurumurthy and Chami, 2019), participatory technology assessment (Ribeiro, 2019), and the elusiveness of the benefits promised by dematerialisation ${ }^{3}$ (the reduction in the quantity of materials required to deliver the same level of functionality).

Application of raw and interpreted data to societal issues such as economic efficiency, industrial/ agricultural production, healthcare, and education has brought to the fore the concept of "ethics engineering." When broadly understood as guiding principles that engineers are to keep in mind when going about their activity (non-corruption, legality, public good considerations, and so on), one example is Royal Academy of Engineering (n.d.). When interpreted as the weaving of ethical functionality into technology-based products (ethical-by-design), one example is Engin (2018); "compliance engineering" can be interpreted similarly. During times of crisis such as natural disasters and global pandemics, efforts to apply the techniques and tools of data science, AI, and ML to clinical, epidemiological, social media,

\footnotetext{
${ }^{1}$ This Data \& Policy Report is based on a discussion paper presented at the Data for Policy 2017_-Government by Algorithm? conference.

${ }^{2}$ The 4IR "will change not only what we do but also who we are. It will affect our identity and all the issues associated with it: our sense of privacy, our notions of ownership, our consumption patterns, the time we devote to work and leisure and how we develop our careers, cultivate our skills, meet people and nurture relationships" (Schwab, 2016a).

${ }^{3}$ Four illustrative examples are as follows. (a) "The information society promises to dematerialise society and make it more sustainable, but modern office and knowledge work has itself become a large and rapidly growing consumer of energy and other resources" (De Decker, 2016). (b) A simple, quantitative, predictive model for dematerialisation and an empirical examination of 57 case studies found "there is no dematerialization occurring even for cases of information technology with rapid technical progress. Thus, a fully passive policy stance that relies on unfettered technological change is not supported by our results" (Magee and Devezas, 2017). (c) "While it is difficult to accurately estimate the energy cost of the AlphaGo system developed by Google DeepMind when it beat the human champion recently in the ancient game of Go, one can safely assume that the machine consumed about four-orders-of-magnitude higher power ... as compared to the nominally quoted power of $20 \mathrm{~W}$ for the human brain" (Shanbhag, 2016). (d) The Computing Community Consortium report "Thermodynamic Computing" states "Somewhat paradoxically, while avoiding stochasticity in hardware, we are generating it in software for various machine learning techniques at substantial computational and energetic cost. In terms of systems, currently five percent of the power generated in the US is used to run computing systems - this astonishing figure is neither ecologically sustainable nor economically scalable" (Conte et al., 2019).
} 
whole genomic sequence, telephony, and other types of data may relegate ethical, legal, regulatory, and related concerns to an afterthought rather than regard them as integral to the endeavor as statistical methods. The development of models for prognostication in intensive care units requires not just technical refinements but careful implementations according to principles such as autonomy, justice, beneficence, non-maleficence, and explicability (Beil et al., 2019).

Greater awareness of the knowledge economy's materiality and appreciation that the virtual realm is neither ephemeral nor intangible (Bhardwaj, 2018) has significant consequences for the evolution of the 4IR. Notwithstanding system challenges (Stoica et al., 2017), consider AI, a pillar of the business and industrial strategy of the United Kingdom (Department for Business, Energy \& Industrial Strategy, 2017) and many other countries (Dutton, 2018; Castro et al., 2019). Typically, efforts to understand the effects of $\mathrm{AI}$ on and interaction with society encompass tasks such as the following. First, developing principles and tools for assessing and estimating transparency, accountability, fairness, (in)justice, robustness, explainability, and provenance with respect to data, algorithms, and robots. Second, addressing risks to the privacy and autonomy of individuals. Third, ascertaining liability when algorithms make mistakes. Finally, articulating the legal standing of groups whose composition is dynamic because new members join and old ones leave on an ad hoc basis (for instance, the categories induced by Big Data analytics, demographic groups, people on a social network site, and online communities formed in response to crime, transport, health, citizen science, or other social concern) - see, for example, Association for Computing Machinery (ACM) U.S. Public Policy Council and ACM Europe Policy Committee (2017), O’Neil (2017), Torresen (2018), Benjamin (2019), Birhane (2019), Birhane and Cummins (2019), Birhane and van Dijk (2020), Floridi and Cowls (2019), Jordan et al. (2019), Koshiyama and Engin (2019), Marcus (2019), Mietchen et al. (2019), Mittelstadt (2019), Ochigame (2019), Phillips and Mian (2019), Mateos-Garcia (2020), and Raff (2020).

Here, our focus is not the ethical, economic, sociopolitical, historical, and related aspects of applications such as national and international public and private AI for (social) good-related projects (Tekisalp, 2020; AI for Good Foundation (AI4Good), n.d.; ITU, XPRIZE Foundation, 37 United Nations agencies, and ACM, n.d.; Sharma, n.d.; Villani, n.d.). Rather, while concrete machines, networks, and networked systems implement computational abstractions, mediate organism-machine "mergers," support dynamic groups, and perform other functions which may be perceived as "phantasmagorical" by the general public, the resource-related aspects of AI/ML itself has received less attention. That is, the material aspects of this technology per se is also a societal issue, not least because practical topics and externalities such as scalability and sustainability (Moore, 2019; Schwartz et al., 2019) raise concerns about, for instance, the physical resources, human labour, and data required to run a large-scale AI system (Crawford and Joler, 2018). The social, built, and natural environments in which AI is embedded and the matter with a real and independent existence embodied in $\mathrm{AI} / \mathrm{ML}$ — metals, minerals, energy, water, land, and so on — are equally noteworthy.

The ICT/EEE ecosystem is a downstream outcome of research and development performed at universities, companies, the military, and other organisations. Given their fundamental role in shaping the present and charting the future, such institutions can make important contributions to militating against the knowledge economy's deleterious resource-related impacts. Although not a formal case study, this work is one step towards realising this potential: an empirical investigation of the resource footprint of an academic computer science department. We take measure of, and interrogate the energy, (raw) materials including water, space, and time footprint of the Department of Computer Science UCL. Our focus is the complex, indeterminate, and ever-changing nature of the challenges we face with respect to the resources consumed by the buildings (place), their occupants (people), and their activities (pedagogy).

In the "Background" section, we provide the context for this up-close and in-depth self-examination (including a bird's eye view of the Department). Then in the "Pedagogy" section, we discuss the present state of affairs and suggest ideas for the future. For reasons of space, similar discussions of Place and 
People are available as Supplementary Material. In the "A more resilient and healthier Department" section, we sketch three interlinked paths in our roadmap for the Department. Finally in the "Concluding remarks" section, we discuss the limitations of this study and highlight the need for national and international bodies such as United Kingdom (UK) Research and Innovation (UKRI) to develop policies and guidelines on the resource footprint of research projects, organisations, and facilities supported by public funds. Since computer science departments and nonuniversity computing centres elsewhere have similar missions, our approach, observations, roadmap, and high-level principles provide starting points they can tailor, adapt, and generalise to suit their own needs. With this introspection, we hope to identify and highlight the direct responsibility of computer scientists/engineers with respect to issues of resilience and sustainability and to place them at the forefront of our community.

In March 2020 as a response to the coronavirus outbreak, UCL shifted from day-to-day operations out of its campus to remote teaching, learning, and services. This ongoing event means that the Department's current pattern of resource consumption is radically different from that described here: from the buildings being largely unoccupied because people are working from home to enormous stresses being placed on our communication networks, personal computers, and data centres as well as the larger ICT/EEE ecosystem in which they are embedded; all activities are occurring online, for instance, videoconferencing has replaced in-person meetings. Beyond impacts on the usage and resiliency of energy and telecommunications infrastructure (McWilliams and Zachmann, 2020; Stolton, 2020), the COVID-19 pandemic is raising the profile of the precautionary principle (Eyres, 2020), showing the value of caution as a guiding influence on our future understanding of the technical and nontechnical aspects of how to create living laboratories for teaching and learning about resource-constrained computing, computation, and communication (Cordes, 2020). We hope this self-reflection initiates broader conversations among and between students, staff, researchers, policy makers, funding agencies, the general public(s), and other stakeholders on what it means to be a resilient and healthy computer science department. We propose that the food, fibre and dye ecosystem ${ }^{4}$ provides lessons for the ICT/EEE (and biological) ecosystem of which the Department is an integral part. In turn, our place-people-pedagogy framework can inform analogous efforts by stakeholders in, for instance, the health ecosystem (Abbasi, 2020) - "studies from the UK, US, Australia, and Japan indicate that healthcare's climate footprint is equivalent to $4.4 \%$ of global net emissions" (Pencheon and Wight, 2020).

Despite the aforementioned caveat, our enquiry can inform the development of more holistic approaches to the governance and assessment of converging disruptive technologies and future spaces at the physical-digital-biological interface. We envisage new "ways of seeing" (Berger, 1972) society and the environment as well the genesis of these interacting realms (Dürrenmatt 2006; Matlack, 2012). For instance, stakeholders exploring the implications of data-driven technologies, automation, molecular technologies, or earth-system engineering approaches could widen the spectrum of factors they take into account by inspecting their subject using the lenses of the recently proposed $F L E^{5} S H$ framework $(F=$ Financial, $L=$ Legal, $E^{5}=$ Economic, Ethical, Equity, Environmental, and Ecosystem, $S=$ Sociopolitical, $H=$ Historical) (Phillips and Mian, 2019). ${ }^{5}$

\footnotetext{
${ }^{4}$ In order not to jeopardise the sustainability of Earth system processes, the EAT-Lancet Commission proposed six absolute planetary boundaries within which food production should operate: global scale targets for greenhouse gas emissions, nitrogen and phosphorus cycling, freshwater use, biodiversity loss, and land-system use (Willett et al., 2019). Limitations of these environmental indicators include an inability to capture all issues and the risks of overlooking crucial or underestimating known factors when applied at the global, regional, national, and/or local level; see, for example, Schuftan et al. (2014), Taylor (2018), CarrascoTorrontegui et al. (2020), Hanieh et al. (2020), Kennedy et al. (2020), and Moberg et al. (2020). Adopting a whole supply chain/ network perspective on the food system takes into account myriad actors and their spatiotemporal relationships: from farm-to-fork, an understanding of which people/interactions are measured and who/what is missing. Similar soil-to-soil arguments have been made for textile production, for example (Burgess, 2019). Thus, using a holistic approach to food, fibres and dyes can help identify and thus avoid life cycle "leakages" and externalising costs to our communities, environment, and their (inter)relationships.

${ }^{5}$ It has been observed that "If we really want transformation, we have to slog through the hard stuff (history, economics, philosophy, art, ambiguities, contradictions). Bracketing it off to the side to focus just on technology, or just on innovation, actually prevents transformation" (Bratton, 2013). Looking further afield (e.g., Mian and Rose, 2011; Rose et al., 2019),
} 


\section{Background}

\section{Energy consumption: the rebound effect or Jevons paradox}

In the academic and public spheres, there is increasing acceptance of the vast quantities of power utilised by the ICT/EEE ecosystem and awareness that the anticipated efficiency savings of new technologies or other measures are often partly or completely clawed back by behavioural changes (Walsh, 2013; De Decker, 2014; LaMonica, 2014; Gurzu, 2017; Santarius, 2017; Turpin, 2017). The latter phenomenonthe rebound effect or Jevons paradox (Ruzzenenti et al., 2018) — occurs when innovations in production or consumption induce an increase in energy consumption that offsets the technology-derived saving (Stern, 2011). Building on the concept of energy efficiency rebound, the circular economy rebound is said to occur when "circular economy activities, which have lower per-unit-production impacts, also cause increased levels of production, reducing their benefit" (Zink and Geyer, 2017). Resource-related aspects of elements of the ICT/EEE ecosystem such as data centres ${ }^{6}$ networks, ${ }^{7}$ DLT and blockchain, ${ }^{8}$

we speculate that concepts and insights about the origins (evolution and ecology), generation (morphogenesis), maintenance (homeostasis and resilience), subversion (pests, pathogens, infectious diseases, and chronic disorders), and decline (ageing) of complex form and function (particularly multicellular systems such as microbial communities, metazoan tissues, and hosts plus their microbiomes - animals/plants and their associated beneficial, opportunistic, and commensal microbes) could illuminate and thereby proffer a fuller picture of today's ICT/EEE ecosystem as well as afford a more comprehensive perspective on proposals for tomorrow's networks of intercommunicating (a)biotic elements.

6 "Everyone prefers to talk about the efficiency of individual data centers, or the proportion of renewable energy they use. No one talks much about total energy used by data centers because the figures you get for that are annoying, depressing, and frustrating. The plain fact is that, no matter how efficiently we run them, data centers are expanding uncontrollably, and consuming increasing amounts of power. In fact, the efficiency improvements are contributing to the rapid growth" (Judge, 2016). Based on estimates of current trends, data centres (servers, storage, network equipment, and infrastructure) in the United States of America (USA) are projected to consume $\sim 73$ billion kWh in 2020 (Shehabi et al., 2016). Data centres consume vast quantities of water during generation and transmission of electricity to the site and by cooling systems at the site itself (Shehabi et al., 2016).

${ }^{7}$ Nearly all signals are transmitted over optical fibres at some point along their route. Communication networks will need to deploy techniques of scarce resource management to overcome technical limitations (wireless spectrum, common public radio interface, network management, and switching and software) and socioeconomic influences (network neutrality, innovation with the creative industries, latency, and energy) (Ellis et al., 2016). To control congestion within a data centre network, approaches are being developed to coordinate transfers of data among large populations of servers (Handley et al., 2017), but if demand for data services such as video continues to grow, the total energy use by communications networks is projected to rival all other energy use (Monroe, 2016). The CAP theorem states that a distributed system consisting of a set of computing nodes that communicate over some network - each node consists of memory that stores data - can provide only two of the following three properties: consistency (return the right response to a request), availability (return a response to each request), and partition tolerance (support message delays and losses) (Gilbert and Lynch, 2002).

${ }^{8}$ DLT is a database that is spread across several independent computing devices, updates are constructed and recorded by each participant "node" of the network, and the ledger is not maintained by any central authority or server-voting and agreement on one copy of the ledger by the nodes is conducted by a consensus algorithm; data quality can be maintained by database replication and computational trust (Extance, 2017; Holmes, 2017). Pioneered by cryptocurrencies such as Bitcoin, blockchains are a form of DLT where data are organised into blocks, the blocks are linked together and secured using cryptography, and entries are updated using an append-only structure meaning previously entered data are not allowed to be altered or deleted (Hull, 2017; Davidson et al., 2018; Niranjanamurthy et al., 2018). The dependability of blockchain-based systems such as Ethereum and Bitcoin (Weber et al., 2017) is critical for applications such as managing, processing, and tracing financial, legal, physical, or electronic assets across a network of parties irrespective of geography (Kakushadze and Russo, 2018; Saberi et al., 2018). Technical hurdles hindering blockchain from mass adoption include scalability (e.g., latency and network speed, size, reliability, and efficiency), security (e.g., network and user privacy), usability (network and user), accountability (e.g., trust and data quality), performance, and resource requirements (e.g., energy consumption, physical hardware needed to implement computational abstractions, and resilience and robustness of communication networks) (Mirzayi and Mehrzad, 2017; Gatteschi et al., 2018; Joshi et al., 2018; Mendling et al., 2018; Raghavan, 2018) - in essence, information storage efficiency, communication efficiency, and energy efficiency. Nontechnical concerns with respect to food sovereignty have been raised (Mooney, 2018). 
cryptocurrencies, ${ }^{9} \mathrm{ML},{ }^{10}$ and computer numerical controlled machine tools (3D printers) ${ }^{11}$ continue to be of interest.

\section{Life cycle analysis: cradle-to-grave}

ICT/EEE ecosystem components utilise resources across their entire life history with their environmental and ecological footprint being visible in multiple places: from mining (exploration, extraction, and processing) of nonrenewable materials and manufacturing, through production and transportation, to utilisation and disposal (De Decker, 2009; Piccirillo, 2011; Dunlap, 2019; Electronics Takeback Coalition, n.d.; Singer, n.d.). ${ }^{12}$ Concerns about day-to-day operational use of digital technology include the increasing demand for power, the growing need for raw materials, the generation of ever larger amounts of plastic waste (Geyer et al., 2017; Liboiron, 2018) (including by 3D printers, Brice, 2017), and the emission of greenhouse gases (Parks and Starosielski, 2015). In 2011, the number of digital electronic and radio-frequency identification-chipped devices connected wirelessly to the internet was projected to reach 50 billion by 2020, or $\sim 7$ per person (Evans, 2011). According to the Solving the E-waste Problem (StEP) international initiative, "e-waste" covers all types of EEE and their parts that have been discarded

\footnotetext{
${ }^{9}$ Key sectors of the global cryptocurrency industry (exchanges, wallets, payments, and mining) have large energy footprints (Fairley, 2017; Giungato et al., 2017) with miners recognising the negative environmental externalities of their activities (Hileman and Rauchs, 2017). One question about the feasibility of broad adoption of DLT platforms (Tymoigne, 2013; Malanov, 2017; Stinchcombe, 2017; Meiklejohn, 2018) is whether decentralised blockchains can match the performance of mainstream payment processors: scalable and sustainable real-time advanced analytics (Bano et al., 2017). Although estimates vary, a recent calculation suggests the electricity consumption of the Bitcoin network is $\sim 1.075 \mathrm{GW}$, roughly one third of the entire country of Ireland (Daian and Juels, 2017). An analysis of stolen bitcoins from legal, economic, and engineering perspectives made eight recommendations for future regulation, one proposal being a carbon tax levied on cryptocurrency mined using proof-of-work methods (Anderson et al., 2018). There is a performance gap: a Visa credit card takes seconds to confirm a transaction, whereas the latency of today's Bitcoin is at least $10 \mathrm{~min}$. The former processes 2,000 transactions/s on average (with a peak rate of 56,000 transactions/s), whereas the latter achieves a maximum throughput of 7 transactions/s (Croman et al., 2016). In the Bitcoin network of 5,400 full nodes, the cost per confirmed transaction may be as high as $\$ 6.20$ - the operational costs (mainly electricity) and capital equipment costs (mining, transaction validation, bandwidth, and storage) (Croman et al., 2016). Thus, "fundamental protocol redesign is needed for blockchains to scale significantly while retaining their decentralization" (Croman et al., 2016).

${ }^{10}$ The huge amounts of training examples and massive computing resources required to solve object detection, speech recognition, translation, robotics, and other problems have spurred development of data-efficient ML, attaining the same performance but in a sample-efficient manner (Deisenroth et al., 2016). Whereas the main motivation is applications in datalimited domains, a virtue of learning with sparse data even in Big Data settings is reduced resource costs. AI is shifting toward the edge, analysing data locally on a sensor or device rather than processing data remotely on a cloud. This trend is fueled by factors such as the high cost of communication, limits on network capacity and architecture, constraints on latency, privacy, cybersecurity, global availability, and the volume and velocity at which data are being generated (Perry, 2017). Since reducing data movement conserves energy, the joint design of algorithms and hardware can produce energy-efficient dataflows while maintaining accuracy, throughput, and cost (Sze et al., 2017a; Sze et al, 2017b).

${ }^{11}$ The 3D printing process requires both primary and second energy: intrinsic or direct energy needed to change the form and properties of a material and extrinsic or indirect energy consumed by components that realise and support the printing process such as drive motors and environmental health and safety equipment (Peng, 2016). A life cycle assessment study of a product offering the same equivalent function (eyeglass frames) manufactured under a digitally supported distributed manufacturing system and a conventional mass scale centralised manufacturing system identified additive manufacturing-triggered increased consumption as one threat to the former system's environmental sustainability (Cerdas et al., 2017).

${ }^{12}$ For example, the lifespan of modern microwave ovens is nearly 7 years shorter than it was almost two decades ago plus their environmental impacts include high levels of electricity consumption, depletion of abiotic elements, human and aquatic toxicities, and creation of photochemical oxidants (Gallego-Schmid et al., 2018). However, this cradle-to-grave study considered only the EEE itself. For "smart" microwaves (Martin, 2018), the system boundaries will need to be expanded to include ICT-related resource costs and impacts, so their environmental burden can only increase. The percent of tungsten, tin, tantalum, and gold consumed by ICT products in 2018 is projected to reach 4\%, 0.3\%, 27\%, and 5\% of global shipments respectively (Fitzpatrick et al., 2015). A study of the recycling of desktop and laptop computers in Belgium found that it saves $80-87 \%$ of the natural resources compared to landfill and that base metals but not precious metals and plastics were recycled efficiently (van Eygen et al., 2016).
} 
by the owner as waste without the intention of reuse (Kuehr, 2014). ${ }^{13} \mathrm{E}$-waste is a product of the largest and fastest growing manufacturing industries: $\sim 41.8$ million metric tonnes (Mt) was generated in 2014 and could reach $50 \mathrm{Mt}$ by 2018 (Baldé et al., 2015); the total may escalate to $100 \mathrm{Mt}$ by 2020, probably more given current research and development in areas such as the Internet of Things and wearable technology (Zhang et al., 2012; Agyepong, 2014). ${ }^{14}$ Across a wide range of geospatial and temporal scales, the ICT/EEE ecosystem affects not just human and environmental health (Harkinson, 2015; Rucevska et al., 2015; Ahmed, 2016) but also (agricultural) biodiversity. ${ }^{15}$

\section{UCL Computer Science: a bird's eye view}

In order to quantify the Department's resource footprint, we would require full cost accounting models for every activity, product, process, service, and infrastructure: systematic approaches that identified, summed, and reported the costs involved in the complete life cycle - from direct private costs, through indirect private costs, to social, environmental, and other costs (Dutta and Hasan, 2013). Clearly, enunciating what we need models for, pinpointing appropriate models, collecting relevant data, and applying models in the real world are nontrivial tasks. To comprehend the magnitude of this task, a short overview of the Department and a brief explication of the activities that take place in pursuit of its goals is useful. Every activity takes place in a specific building and/or utilises various defined ICT/EEE elements. Each location in and of itself consumes resources such as electrical energy, water, and space. Every service consumes resources and requires other hardware and software for its operation. The manufacture, transport, installation, and decommissioning of physical hardware generates greenhouse gas emissions and waste. For each activity, the agents or actors involved include staff, students, and external providers such as the higher organisational and academic structures in which the Department is embedded. Some factors can be quantified fairly precisely (e.g., the electrical power consumed by a server and the number of bits through a network port), others can be approximated only because they pass outside the control of the Department (e.g., hardware manufacturers), and many — if not most — cannot be measured at all (but it may be possible to determine their contribution to the total).

Consider the Department's undergraduate module on ML. Designed to enhance its teaching provision, this course attracted an extra 20 students in the 2017-2018 academic year, a number that will increase in subsequent years given its popularity. The students need physical space in the form of, for example, classrooms that require heating, ventilation, cooling, and electrical power. The ICT/EEE services they need will consume resources. The two new graphics processing unit (GPU) servers provided to facilitate teaching require $6 \mathrm{U}$ of rack space and add an extra $3 \mathrm{~kW}$ to the power drawn by the Department; this in

\footnotetext{
${ }^{13}$ Any household or business item with circuitry or electrical components with power or a battery supply such as computers, mobile telephones, televisions, monitors, laptops, tablets, smartphones, printers, MP3 players, games and gaming equipment, white goods (refrigerators, washing machines, dryers, air conditioners, and so on), robots, drones, cables, and routers (Pérez-Belis et al., 2015).

${ }^{14}$ A study of 50 countries in the pan-European region found that an increase in the gross domestic product at purchasing power parity generates additional e-waste that requires management (Kusch and Hills, 2017). Whereas absolute growth of the world economy has a significant influence on the annual growth of atmospheric $\mathrm{CO}_{2}$ levels, there is no observable relationship between $\mathrm{CO}_{2}$ concentrations and short-term growth of world population (Granados et al., 2012).

${ }^{15}$ For example, the electromagnetic radiation of mobile telecommunication antennas can affect wild pollinator abundance and composition (Lázaro et al., 2016). Heavy metals and persistent organic pollutants produced as a result of (in)formal e-waste recycling activities can contaminate soil and water at the recovery site as well as nearby farmland threatening humans, crops, and livestock (Amfo-Otu et al., 2013; Liu et al., 2013; Zhang et al., 2015; Landrigan et al., 2018). Current energy and raw material consumption, land use, and pollution (Landrigan et al., 2018) are key drivers of change of biodiversity for food and agriculture (Commission on Genetic Resources for Food and Agriculture, 2019) and factors contributing to the degradation and contamination of soil, a nonrenewable resource whose preservation is essential if current and future generations are to meet their food, feed, fibre, dye, medicine, fuel, and other needs (Food and Agriculture Organization of the United Nations, 2015; Suárez-Torres et al., 2017). In toto, the integrity, stability, and beauty of natural (agro)ecosystems ought not to be undermined, particularly because agroecology offers solutions to the crises of climate, environment, public health, livelihoods, and economies (Coordination Nationale des Organisations Paysannes du Mali (CNOP), et al., 2015; Wright, 2012; Mulvany, 2014; Shannon et al., 2015).
} 
turn requires an equivalent amount of cooling. The manufacturer does not disclose the resources consumed during their production and transport, but UCL disposes of their packaging $\sim \sim 25 \mathrm{~kg}$ of cardboard, expanded polythene foam, and the pallet on which they were transported - through an external recycling company. These servers utilise a portion of the existing network and storage infrastructure. The course uses a cloud software package, provided free of charge by the vendor, but this adds additional network load throughout the path, consuming resources wherever the vendor is hosting the cloud application. The bandwidth consumed by the application can be measured on the departmental router, allowing an estimate of Watts per bit to be established.

After 3-4 years of use, the servers will be replaced by the next generation of hardware. The Department will continue to operate the original machines as part of a general compute/GPU cluster for another 3-4 years. As this period will exceed the hardware's "normal" lifespan, each component will be out of warranty and so not replaced as it fails. Any useful parts that are compatible with other devices (such as power supplies) will be kept — but these need to be stored and as is often the case, may never see usage again. On final removal from the Department, UCL Estates and Facilities disposes of the hardware through an external e-waste company. In the absence of information about the company's practices, it is unknown how much material is ultimately extracted, whether this is recycled into the manufacturing process, and the energy costs of either or both. ML-related teaching and research activities are part and parcel of academic computer science department worldwide, so although the exact settings and precise circumstances will vary from place to place, many of the problems and difficulties we have described will be familiar.

The heterogenous nature of the Department's research and funding sources is reflected in the bespoke nature of its research infrastructure and data centre. Thus, in order to calculate a metric such as data throughput, CPU cycles, power, and temperature when ascertaining consumption of a particular resource, a substantial amount of time and effort would be required to gather consistent and relevant information from a plethora of agents and actors. We expect other academic computer science departments wishing to determine energy efficiency metrics for their own data center (Newcombe, 2008) will encounter similar hurdles.

\section{Pedagogy - Teaching, Learning, Investigating, and Other Activities}

\section{Present state of affairs: classroom}

\section{Green computing}

Green IT is the "study and practice of designing, manufacturing, using and disposing of computers, servers and associated subsystems - such as monitors, printers, storage devices and networking and communications systems - efficiently and effectively with minimal or no impact on the environment. Green IT also strives to achieve economic viability and improved system performance and use, while abiding by our social and ethical responsibilities" (Murugesan, 2008). Environmental sustainability, the economics of energy efficiency, and the total cost of ownership (including that of disposal and recycling) fall under the rubric of "green" computing. Ideas such as green networking and energy-aware security (Merlo et al., 2015) are of practical and theoretical relevance: from materials to devices to circuits to complete systems, fundamental limits to computation exist in areas such as manufacturing, energy, physical space, design and verification, and algorithms (Markov, 2014). Currently, the Department has few undergraduate/postgraduate courses, reading groups, or other vehicles that could be categorised as addressing green computing-related problems and solutions.

\section{Ideas for the future: resource-constrained computing, computation, and communication}

\section{Resource-efficient hardware, software, and security}

The Department could chart a course toward resource use being both minimised and minimal by incorporating the concept of resource-constrained computing, computation, and communication into the fabric of instruction, research, and development - facilitating and encouraging exploration of topics such as quantifying the resources required to achieve a given level of efficiency in hardware (computing), software (algorithms), and security (information transmission in the presence of adversaries and 
eavesdroppers). With respect to developing, training, testing, and running models, "green AI" advocates evaluating accuracy as a function of computational and financial costs (Schwartz et al., 2019). The financial and environmental costs of training a variety of popular off-the-shelf neural network models for natural language processing have been assessed by estimating the kilowatts of energy consumed and converting them into approximate carbon emissions and electricity costs (Strubell et al., 2019); model inference is also of concern (Biewald, 2019). Software systems developers have considered the technical and economic requirements as well as the social and environmental dimensions of their craft (Lago et al., 2015). Realising smaller, lighter, faster, cheaper, and cooler ICT/EEE hardware and software will require advances such as reducing power and raw material consumption, lowering the financial costs of computation and digital preservation, decreasing carbon emissions, lessening environmental impact, improving systems performance and use, and saving physical space (Muelhlhauser, 2014; Rosenthal, 2014). Since using less energy produces less heat waste yielding higher clock speed, reversible computing is one potential solution (Stauffer, 2013; Lynch and Demaine, 2014).

\section{A living laboratory for experimental computer science}

The Department's Technical Support Group (TSG) could explore the feasibility of creating a fully functional machine room that simultaneously enables and facilitates staff and students to observe, monitor, and investigate the operation and behaviour of a complex real-life computing facility. The resultant information could be used to define, refine, and implement solutions for reducing the Department's resource footprint. Unfortunately, calculating efficiency is difficult because the latest processors will switch processing speed depending on workloads but will cap these turbo speeds if particular instructions are used (Intel Developer Zone, 2017). The TSG is performing experiments to ascertain which processor model is best suited to which particular job type(s).

\section{A back to the future interest group}

Informal groupings of staff and students from computer science and other disciplines could re-examine historical technologies and approaches with a view to informing the present and future, culturally and practically. The rebound effect or Jevons paradox refers to expected savings not being (fully) realised because of induced demand (De Decker, 2018; Ruzzenenti et al., 2018). This counterintuitive notion dates back to the industrial revolution: the more efficient use of coal made possible by technology caused the extraction and consumption of more coal rather than the preservation of existing reserves (Jevons, 1865). Work on systemic drivers of this phenomenon concluded that "sustainability cannot be achieved by technological innovations alone, but requires a continuous process of institutional and behavioural adjustment" (Giampietro and Mayumi, 2018). In the late $19^{\text {th }}$ century, the nature and availability of materials such as rubber, gutta-percha, copper, and hessian shaped development of the telegraph and transatlantic communication (Burns, n.d.). Virtually every technology invented in the last 30 yearssmartphones, wind turbines, hybrid/electric cars, MRI scanners, and so on - uses rare earth metals and rare gases (Simpson, 2011; Chao, 2012). Rising demand in the green/clean/alternative technology sectors is depleting rapidly the world's entire supply of strategic materials (MIT Solving Complex Problems, 2012; Bardi, 2014). What more can be learnt from the past's understanding of technology's materiality?

Modern subjects such as latency, bandwidth, and delay (disruption) tolerant networks could draw lessons from the $18^{\text {th }}$-century optical telegraph, a communications network for forwarding coded messages over long distances without the need for wires, electricity, horses, or postmen and an e-mail system that could achieve transmission speeds of $\sim 1,400$ kilometres per hour (De Decker, 2007). From early antiquity, private persons, governments, the military, press agencies, stockbrokers, and others have used carrier pigeons to convey messages. ${ }^{16}$ Sneakernets - the physical transport of classical information stored in removable media — are used today (De Decker, 2015; Chong, 2017; Moss, 2017; Wall, 2017) and

\footnotetext{
${ }^{16}$ One unexpected virtue of such systems is pigeon guano (Villa-Serrano et al., 2010), a substance praised as a super-manure since the Middle Ages and regarded as more valuable than that of other birds.
} 
have been proposed as a low-latency high-fidelity network architecture for quantum computing across global distances: ships carry error-corrected quantum memories installed in cargo containers (Devitt et al., 2016). What more can the evolutionarily ancient method of communication using molecules such as hormones, pheromones, and metabolites (Nakano, 2017) teach us about the virtues of reliably and securely transmitting information (Rose and Wright, 2004; Rose et al., 2019)?

The challenges of digital preservation are technical (rendering accurately authenticated content over time), financial (using limited resources to maximise the value delivered to future users), and legal (the public, private, and criminal law covering the initial conservation and subsequent reuse of and access to data, metadata, documents, and software) (Rosenthal, 2017). Whereas the environmental and economic costs of digital preservation are known (Rosenthal, 2014), less well appreciated are practical consequences of technical properties such as the "fragility of academic communication in the Web era as opposed to its robustness in the paper era" (Rosenthal, 2015). ${ }^{17}$ What is the resource footprint of the policies, strategies, and actions needed to ensure that digital information of continuing value remains accessible and usable?

\section{Horizon scanning interest group}

Informal groupings of staff and students could identify emerging issues in science, technology, engineering, mathematics, and medicine, employ the $F L E^{5} S H$ framework to analyse their implications for society, and sketch out advice on possible future changes, threats, and options for policy makers and Parliament. Consider the following. With predictions of 44 zettabytes of data stored by 2020 (a 10 -fold increase from 2013), there is a need to adopt "a more aggressive policy of data archiving on long-term, low-energy, 'cold' storage" (Hormann and Campell, 2014). Given DNA's remarkable longevity and enormous information density in the natural world (Allentoft et al., 2012), this molecule — on its own or inserted into the genome of a living organism - is seen as an attractive medium for archival storage of digital information (Neiman, 1964; Baum, 1995; Bancroft et al., 2001; Yachie et al., 2008; Extance, 2016; Bornholt et al., 2017; Heckel et al., 2017; de Groot, 2018; Ho, 2018; Lenz et al., 2020; Lima, 2018; Stefano et al., 2018; Tavella et al., 2018). ${ }^{18}$ A February 2018 analysis suggested that $\sim 10$ tons of DNA could store all the world's data, an amount that could fit in a semitrailer (Cornish, 2018).

Technical challenges include lowering costs $\left(\$ 10^{2}\right.$ for storing 1 megabyte in DNA but $\$ 0.0001$ per year using tape), increasing throughput (synthesis and sequencing are inherently slow, whereas access times of hard drives are milliseconds), and reducing errors in writing, reading, storing, and handling nucleic acids (mismatches between the information conveyed by the physical material and the digital data theoretically associated with it - for example, complete loss of DNA strands and aggregate insertion, deletion, and substitution rates of $\sim 0.01$ errors/base) (Heckel, 2018; Heckel et al., 2019; Organick et al., 2018). Predictable information security challenges include the embedding of malware in synthetic DNA (Ney et al., 2017) and cyberbiosecurity threats arising from the underlying bio-automation and biotechnology (Wintle et al., 2017; Peccoud et al., 2018). What extant and new hazards would the convolution of e-waste and biomedical/biological waste (b-waste) pose? What new types of data centres would be required?

\footnotetext{
${ }^{17}$ The root cause of the evanescent Web (Rosenthal, 2015) can be described as follows: "in the paper world in order to monetize their content the copyright owner had to maximize the number of copies of it. In the Web world, in order to monetize their content the copyright owner has to minimize the number of copies. Thus the fundamental economic motivation for Web content militates against its preservation."

${ }^{18}$ The key steps (De Silva and Ganegoda, 2016) in preserving user digital data in strands of DNA and/or synthetic nucleic acids constructed from natural bases and/or their analogues are encoding (converting binary data into a digital nucleotide sequence using an error-correcting code), de novo synthesis (fabricating strands matching the digital nucleotide sequence), storage (preserving actual nucleic acid molecules in an appropriate environment such as low temperature or encapsulation in silica), management (maintaining large repositories of nucleic acid-based datasets over long periods of time), retrieval (fetching entries from a repository and selectively extracting molecules from storage containers, random data access), sequencing (determining the exact order of nucleotides in the strands and generating a digital nucleotide sequence), and decoding (translating the digital nucleotide sequence into binary data).
} 
Still in their infancy, nucleic acid-based systems for data storage and other purposes (Mueller et al., 2016; Song and Zeng, 2018) necessitate the design and orchestration of diverse cyber-physical systems ${ }^{19}$ for many aspects of the encoding, synthesis, storage, management, retrieval, decoding, and other steps. Unappreciated, unrecognised, and unanticipated ways in which this nascent component of the data economy could traverse the physical, digital, and biological spheres raise issues such as scalability, sustainability, (bio)safety (consequences for human, environmental, and ecosystem health), (bio)security (dual use), and (bio)privacy. A full cost accounting model of nucleic acid-based archival storage of digital information will require cradleto-grave studies of known and novel products, processes, services, and infrastructure across their entire life (cf. the practical, financial, ethical, and other aspects of bioresources (Gonzalez-Sanchez et al., 2014)). In toto, what existing techniques and tools as well as new strategies and methods are needed to identify, determine, and assess the short-, medium- and long-term impacts of a nucleic acid-based knowledge economy on the lithosphere, biosphere (including humans and their societies), atmosphere, and hydrosphere?

\section{A More Resilient and Healthier Department: A Roadmap}

Successful development and deployment of a roadmap for the Department requires (a) understanding the basic attitudes, values, and patterns of behaviour that are common to staff and students, including patterns of consumption or nonconsumption; (b) rethinking discarded materials as resources; (c) reducing waste so that it is diverted from landfills, incinerators, and the environment (no burial, burning, or emission into air, water, and land); (d) promoting the interconnected nature of human and environmental health; and (e) scrutinising concepts such as progress and modernity (Nandy, 1988; Merchant, 2006; Mignolo, 2011; Giannella, 2015; Horton, 2017). More broadly, it is important to avoid solutionism, "an unhealthy preoccupation with sexy, monumental, and narrow-minded solutions - the kind of stuff that wows audiences at TED Conferences - to problems that are extremely complex, fluid, and contentious.... solutionism presumes rather than investigates the problems that it is trying to solve, reaching 'for the answer before the questions have been fully asked.' How problems are composed matters every bit as much as how problems are" (Morozov, 2013) (for examples of solutionism in the context of the COVID-19 pandemic, see (Ada Lovelace Institute, 2020; Joseph, 2020; Morozov, 2020)).

Formulating policies and developing guidelines that create a living laboratory for teaching and learning about resource-constrained computing, computation, and communication will require a multi-, trans-, and inter-disciplinary approach. We will need data pertaining to the technical aspects of resource consumption as well as information and ideas relevant to the architectural, human, and philosophical dimensions of the task. Undergirding the making, taking, or advocating of a particular course of action is critical discourse on the viewpoints, uncertainties, contexts, decisions, and/or possible outcomes of proposed directions on the widest possible spectrum of stakeholders. One potential strategy is the establishment of a resource-aware problem-solving laboratory spanning the Department, the Slade School of Fine Art, the Bartlett School of Architecture, the Sarah Parker Remond Centre for the Study of Racism and Racialisation, and members of the general public. By virtue of its ability to examine problems from multiple angles, the resultant UCL Department of $(\mathrm{Re})$ search would be well placed to facilitate dialogue in which participants could probe topics such as energy sufficiency (reducing the growth in energy services as well as the floors and ceilings of energy use) (De Decker, 2018), environmental indicators within which the Department should operate (cf. EAT-Lancet Commission, Willett et al., 2019), and the $F L E^{5} S H$ framework (Phillips and Mian, 2019). Its initial remit might be to explore how the three aims outlined below could be achieved.

\footnotetext{
19 “Cyber-physical systems (CPS) comprise interacting digital, analog, physical, and human components engineered for function through integrated physics and logic" (National Institute Standards and Technology Engineering Laboratory, n.d.). "Embedded computers monitor and control physical processes, usually with feedback loops, where physical processes affect computations and vice versa. Applications of CPS include automotive systems, manufacturing, medical devices, military systems, assisted living, traffic control and safety, process control, power generation and distribution, energy conservation, HVAC (heating, ventilation and air conditioning), aircraft, instrumentation, water management systems, trains, physical security (access control and monitoring), asset management and distributed robotics (telepresence, telemedicine)" (Lee, 2015).
} 


\section{Cap annual power consumption and greenhouse gas emissions}

In the 1990s, researchers proposed a pragmatic step toward a sustainable Western lifestyle whereby each person in the developed world - primarily the USA, Canada, Western Europe, and Australia - would consume no more than $2,000 \mathrm{~W}$ and emit no more than 1 ton of $\mathrm{CO}_{2}$ per year. The idea gained acceptance in the city of Basel and then other regions in Switzerland as well as in Germany. Assessment of the environmental behaviour of $\sim 4,000$ Swiss inhabitants plus a life cycle assessment indicated that whereas restraining energy demand to $2,000 \mathrm{~W}$ is possible, limiting $\mathrm{CO}_{2}$ production to under 1 ton per person per year is difficult (Notter et al., 2013). Defining per person per year caps applicable to each and every member of the Department would be difficult. An alternative might be setting activity- and group sizebased bounds, for instance, lower limits for formal methods and postgraduate courses compared to ML and undergraduate classes. However, the Department is not a hermetically sealed system so even if atomised accounting procedures and mechanisms could be developed, bidirectional movement of people and goods across its porous borders poses challenges such as what fraction of an allowable resource budget should be allocated to an individual with multiple affiliations. Thus, articulating and establishing precise goals for all possible scenarios is likely to be extremely time-consuming and impossible to implement.

A more productive option might be to identify and characterise the most resource hungry practices by soliciting input from stakeholders irrespective of whether they have, do, or will contribute to said usage. Rather than formulating, incentivising attainment, and penalising noncompliance of specific targets, it might be preferable to encourage a sense of individual and collective responsibility, enable co-creation of qualitative as well as quantitative mitigation and/or elimination strategies over a range of spatiotemporal scales. It would be better to foster a shared culture that takes action to reduce resource consumption within our Department but is cognizant of the ripple effect such changes would have on the wider world: our focus should be preparing and promoting a community guide to resilient and healthy computer science departments (see, for example, Conant and Fadem, 2008).

Knowledge of energy efficiency does not necessarily translate into energy savings (technologies designed originally to reduce energy use can give rise to new applications that eventually raise energy consumption as well as technological obsolescence), energy consumption does not equal electricity consumption (an ICT/EEE with a given kilowatt-hours of electricity rating requires the production of a larger amount of energy because the conversion of one form of energy into another is accompanied by loss of energy), and life cycle analyses may be out of date, incomplete, or not exist (the lifespan of a technology bears witness to myriad parts, materials, and processing techniques, each with its own resource requirements) (De Decker, 2009; Zehner, 2012; De Decker, 2018). Barriers to estimating the Department's energy consumption include its complex infrastructure and the fast-changing nature plus rapid evolution of the networks, methods, assumptions, and models researchers employ. Given that the 2012 global communications network (end-use devices, networks, data centres, and manufacturing) is postulated to have consumed $8 \%$ of that year's global energy production and the ever-increasing energy consumption per internet user, a "speed limit for the Internet" has been proposed (De Decker, 2015). Furthermore, reductions in the energy intensity of the Internet (energy utilised per unit of information sent) are more than offset by ever higher total energy use arising from shifting consumption patterns (system-level factors) (De Decker, 2015). Self-imposed limits on the demand side of digital communication is one mechanism for ensuring that resource use is not just minimised but also minimal.

\section{Become a zero waste institution}

Resource life cycles can be redesigned so that all products can be repurposed to serve the same or similar function so that eventually, nothing is sent to landfills and incinerators (Zero Waste International Alliance, n.d.). Higher than the Pollution Prevention Hierarchy, the Zero Waste Hierarchy of Highest and Best Use considers not just the entire carbon life cycle of materials but also the embodied energy used to extract virgin resources, manufacture a product, and transport a product to market. In essence, if a product cannot be "reused, repaired, rebuilt, refurbished, refinished, resold, recycled or composted, then it should be restricted, redesigned, or removed from production." Since sustainable resource management is the joint 
responsibility of producers, communities, and politicians, a UCL Department of (Re)search could make contributions in all three areas: industrial production and design at the front end, a governmental and regulatory landscape in the middle, and consumption, discard use, and disposal at the back end. A UCL Department of (Re)search could be tasked also with articulating what "zero emission" and "zero energy" buildings (Torcellini et al., 2006; MacKay, 2009; Gmach et al., 2010; Wikipedia contributors, n.d.) mean in the context of an academic computer science department.

\section{Rejuvenate and (re)integrate the natural and built environments}

Exposure to and contact with the biome's micro- and macro-organisms may be important for immune development and might reduce several types of diseases and conditions associated with the modern era (Parker and Ollerton, 2013; Rook et al., 2014). Indoor plants provide beneficial bacteria, positively influencing human health (Berg et al., 2014). The Department's indoor and outdoor natural environment is vital to providing a healthy workplace. An agroecological approach to the building's landscape could enhance the well-being of students, staff, and visitors by, for instance, facilitating the flow of beneficial soil- and plant-associated micro- and macro-organisms indoors. Some microbes can induce deterioration of building materials and artifacts such as compact discs (Cappitelli and Sorlini, 2005; Sterflinger and Piñar, 2013; Wei et al., 2014). How might the microbiomes of the Department's enclosed private and public spaces affect the daily to long-term operation of its ICT/EEE and vice versa? A "seed-to-skin-tosoil" approach has been applied to a hoodie grown, designed, and crafted using materials from a 150 mile supply chain where, at the end of its life, the nutrients in the composted garment (apart from the metal zip) could be returned to pasture or farmland used to produce fibres and dyes and hence raw materials for subsequent hoodies (Anderson, 2014). Is an analogous "soil-to-soil" philosophy (Fibershed, n.d.) for ICT/EEE feasible?

\section{Concluding Remarks}

This self-deliberation focused on characterising the resource footprint of the Department of Computer Science UCL. Beyond the factors discussed here, a full accounting will require identifying and enumerating all manner of externalised costs such as off-site data centres, not least their energy, land, raw material, and water requirements. Despite such limitations, practical steps toward a minimal power consuming, minimal greenhouse gas emitting, and zero waste Department where the natural and built environments are (re)integrated do exist. Design philosophies rather than specific technologies are key: for example, passivhaus, ecological sanitation, rainwater harvesting, and agroecology are place-based approaches that are shaped by local landscapes, communities, building materials, and climate (such issues are discussed in the Supplementary Material). Buildings are not merely mechanical entities that can be deconstructed into parts with certain dimensions - windows and doors of a certain height, area, and volume. Rather, they are socio-technical-ecological networks whose organisation and dynamics are governed both by the physical structure and interactions among and between their (a)biotic components across wide spatiotemporal scales.

Major infrastructure can last for 30-100 years, and even academic curricula have a life span of many years. Thus, the earlier and faster the Department understands the many facets of resource-constrained computing, computation, and communication and mitigates or eliminates its consumption of resources, the less adaptation will be required in the future. We propose two maxims to aid policy making and guideline preparation. First, resource use needs to be both minimised and minimal: reduced in relative as well as in absolute terms. Second, responsible research and innovation (RRI) entails not just decreasing the resource footprint of a research facility, organisation, institution, or project but also considering nontechnological solutions to complex real-world problems and the opportunity costs when the ICT/EEE ecosystem is the first port of call for answers.

Other academic computer science departments can exploit our findings to develop their own roadmaps. For example, the technology company Nvidia produces GPUs for the gaming, cryptocurrency, and 
professional markets, but its DGX-1 supercomputer is aimed at ML tasks in high-performance data centres, for example, accelerating the use of deep learning by combining GPUs with integrated deep learning software. Our current experiments with Nvidia's DGX-1 machines show that they each consume $\sim 3 \mathrm{~kW}$, and if we are to include the amount of energy required to efficiently cool these systems, then we are consuming $\sim 3.5 \mathrm{~kW}$. After many hours (and kWh) of training, a student may identify an image such as that of a cat with close to $100 \%$ reliability. How users respond to energy-related information about their computations is a topic for further investigation. Beyond this, one of us (D.A.T.) has direct experience of managing a national computing facility funded by the UK's Engineering and Physical Sciences Research Council (EPSRC) and where one of the first considerations was the ability to power such a system (Giles et al., 2016). Free to all academic users, this Joint Academic Data Science Endeavour high-performance computing resource is designed to support the needs of ML and related data science applications at six university partners.

According to the EPSRC, "responsible innovation is a process that seeks to promote creativity and opportunities for science and innovation that are socially desirable and undertaken in the public interest" (EPSRC, n.d.). Its AREA (Anticipate, Reflect, Engage, Act) framework (EPSRC, n.d.) seeks to (a) describe and analyse "the impacts, intended or otherwise, (for example economic, social, environmental) that might arise. This does not seek to predict but rather to support an exploration of possible impacts and implications that may otherwise remain uncovered and little discussed"; (b) reflect on "the purposes of, motivations for and potential implications of the research, and the associated uncertainties, areas of ignorance, assumptions, framings, questions, dilemmas and social transformations these may bring"; (c) open up "such visions, impacts and questioning to broader deliberation, dialogue, engagement and debate in an inclusive way"; and (d) use "these processes to influence the direction and trajectory of the research and innovation process itself." Similarly, "ProGReSS" is a European Commission-funded project whose mission is to promote a European approach to RRI: "research and innovation which is ethically acceptable, sustainable by avoiding significant adverse effects and drives towards the common good, i.e., societal desirability" (European Union, n.d.).

Operating across the whole of the UK with a combined budget of more than $£ 7$ billion, UKRI brings together the EPSRC, Arts and Humanities Research Council, Biotechnology and Biological Sciences Research Council, Economic and Social Research Council, Medical Research Council, Natural Environment Research Council, Science and Technology Facilities Council, Innovate UK, and Research England (United Kingdom Research and Innovation (UKRI), n.d.). As part of its newly launched environmental sustainability strategy, UKRI "aspires to be 'net-zero' for its entire research undertaking, including reducing and mitigating all carbon emissions from owned operations, and looking beyond carbon to ensuring its wider environmental contribution is a positive one" (United Kingdom Research and Innovation (UKRI), 2020). This study highlights the need for new policies and guidelines on the resource footprints of academic departments, research projects, and e-infrastructure. These could be developed using the findings of a report prepared by a national working group convened by UKRI.

Acknowledgments. We thank E. Kazim, T. Stevens, F. Murtagh, C. Wardle, and P. Stenetorp for comments on the manuscript.

Funding Statement. This work received no specific grant from any funding agency, commercial or not-for-profit sectors.

Competing Interests. The authors declare no competing interests exist

Authorship Contributions. Conceptualization, I.S.M. and D.A.T.; Methodology, I.S.M., D.T., and D.A.T.; Investigation, I.S.M., D.T., and D.A.T.; Writing-original draft, I.S.M.; Writing-review \& editing, I.S.M., D.T., and D.A.T. All authors approved the final submitted draft.

Data Availability Statement. Data availability is not applicable to this article as no new data were created or analysed in this study.

Ethical Standards. The research meets all ethical guidelines, including adherence to the legal requirements of the study country.

Supplementary Material. To view supplementary material for this article, please visit http://dx.doi.org/10.1017/dap.2020.12. 


\section{References}

Abbasi K (2020) Bad science in a plastic world. Journal of the Royal Society of Medicine 113, 47. Available at https://doi.org/ $10.1177 / 0141076820905749$.

Ada Lovelace Institute (2020) Exit through the App Store? Should the UK Government use technology to transition from the COVID-19 global public health crisis. Available at https://www.adalovelaceinstitute.org/exit-through-the-app-store-how-theuk-government-should-use-technology-to-transition-from-the-covid-19-global-public-health-crisis/.

Agyepong H (2014) The gaze on Agbogbloshie. Available at http://www.heatheragyepong.com.

Ahmed SF (2016) The global cost of electronic waste. The Atlantic. 29 September 2016. Available at https://www.theatlantic.com/ technology/archive/2016/09/the-global-cost-of-electronic-waste/502019/.

AI for Good Foundation (AI4Good) (n.d.) Building lasting communities that bring the best technologies to bear on the world's most important challenges. Available at https://ai4good.org/about/ 26th July 2020.

Allentoft ME, Collins M, Harker D, Haile J, Oskam CL, Hale ML, Campos PF, Samaniego JA, Gilbert MT, Willerslev E, Zhang G, Scofield RP, Holdaway RN and Bunce M (2012) The half-life of DNA in bone: Measuring decay kinetics in 158 dated fossils. Proceedings of the Royal Society B: Biological Sciences 279, 4724-4733. Available at https://doi.org/10.1098/ rspb.2012.1745.

Amfo-Otu R, Bentum JK and Omari S (2013) Assessment of soil contamination through e-waste recycling activities in Tema Community One. Environment and Pollution 2, 66-70. Available at http://dx.doi.org/10.5539/ep.v2n2p66.

Anderson C (2014) North Face attempts to make all-local hoodie, using some Yolo County cotton. Available at http://www. sacbee.com/news/business/biz-columns-blogs/cathie-anderson/article4129919.html.

Anderson R, Shumailov I, Ahmed M and Rietmann A (2018) Bitcoin Redux. Cambridge, UK: Cambridge University Computer Laboratory. Available at https://www.cl.cam.ac.uk/ rja14/Papers/bitcoin-redux.pdf.

Association for Computing Machinery (ACM) U.S. Public Policy Council and ACM Europe Policy Committee (2017) Algorithmic transparency and accountability. Available at https://sigai.acm.org/aimatters/blog/2017/06/01/algorithmic-transpar ency-and-accountability/.

Autorité de la concurrence and German Bundeskartellamt (2019) Algorithms and competition. Available at https://www. bundeskartellamt.de/SharedDocs/Publikation/EN/Berichte/Algorithms_and_Competition_Working-Paper.html.

Baldé CP, Wang F, Kuehr R and Huisman J (2015) The global E-waste monitor-2014. Institute for the Advanced Study of Sustainability, United Nations University. Available at https://i.unu.edu/media/unu.edu/news/52624/UNU-1stGlobal-E-WasteMonitor-2014-small.pdf.

Bancroft C, Bowler T, Bloom B and Clelland CT (2001) Long-term storage of information in DNA. Science 293, $1763-1765$. Available at https://dx.doi.org/10.1126/science.293.5536.1763c.

Bandara P and Carpenter DO (2018) Planetary electromagnetic pollution: It is time to assess its impact. Lancet Planet Health 2 , e512-e514. Available at https://doi.org/10.1016/S2542-5196(18)30221-3.

Bano S, Al-Bassam M and Danezis G (2017) The road to scalable blockchain designs. Login: The Usenix Magazine 42, 31-36. Available at https://www.usenix.org/publications/login/winter2017/bano

Bardi U (2014) Extracted. Chelsea Green, U.S.A.. Available at https://www.chelseagreen.com/product/extracted/

Bassey N (2019) Science, technology and innovation: Implications for Africa. Development 62, 116-120. Available at https:// doi.org/10.1057/s41301-019-00201-8

Baum EB (1995) Building an associative memory vastly larger than the brain. Science 268, 583-585. Available at https:// dx.doi.org/10.1126/science.7725109.

Beil M, Proft I, van Heerden D, Sviri S and van Heerden PV (2019) Ethical considerations about artificial intelligence for prognostication in intensive care. Intensive Care Medicine Experimental 7, 70. Available at https://doi.org/10.1186/s40635-0190286-6.

Benjamin R (2019) Assessing risk, automating racism. Science 366,421-422. Available at https://doi.org/10.1126/science. aaz3873.

Berg G, Mahnert A and Moissl-Eichinger C (2014) Beneficial effects of plant-associated microbes on indoor microbiomes and human health? Frontiers in Microbiology 5, 15. Available at http://dx.doi.org/10.3389/fmicb.2014.00015.

Berger J (1972) Ways of Seeing. Penguin Books, U.K.. Available at https://www.penguin.co.uk/books/56465/ways-of-seeing/ 9780141035796.

Bhardwaj P (2018) Fiber optic wires, servers, and more than 550,000 miles of underwater cables: Here's what the internet actually looks like. Business Insider, 09 June 2018. Available at https://www.businessinsider.nl/how-internet-works-infrastructurephotos-2018-5.

Biewald L (2019) Deep learning and carbon emissions. Towards data science, 18 June 2019. Available at https:// towardsdatascience.com/deep-learning-and-carbon-emissions-79723d5bc86e.

Birhane A (2019) The algorithmic colonization of Africa. Abeba Birhane. Anti-Cartesian rants, mainly, 10 July 2019. Available at https://abebabirhane.wordpress.com/2019/07/10/the-algorithmic-colonization-of-africa/.

Birhane A and Cummins F (2019) Algorithmic injustices: Towards a relational ethics. arXiv:1912.07376 [cs.CY]. Available at https://arxiv.org/abs/1912.07376.

Birhane A and van Dijk J (2020) Robot rights? Let's talk about human welfare instead. In AIES '20: Proceedings of the AAAI/ACM Conference on AI, Ethics, and Society, pp. 207-213. Available at https://doi.org/10.1145/3375627.3375855. 
Bornholt J, Lopez R, Carmean DM, Ceze L, Seelig G and Strauss K (2017) Toward a DNA-based archival storage system. IEEE Micro 37, 98-104. Available at https://doi.org/10.1109/MM.2017.70.

Bratton B (2013) We need to talk about TED. The Guardian, 30 December 2013. Available at http://www.theguardian.com/ commentisfree/2013/dec/30/we-need-to-talk-about-ted.

Brice A (2017) As 3D printing grows, so does need to reclaim plastic waste. Berkeley News, 15 February 2017. Available at http:// news.berkeley.edu/2017/02/15/3d-printer-filament-reclamation-project/.

Burgess R (2019) Fibershed: Growing a Movement of Farmers, Fashion Activists, and Makers for a New Textile Economy. White River Junction, VT: Chelsea Green Publishing. Available at https:/www.chelseagreen.com/product/fibershed/.

Burns B (n.d.) History of the Atlantic Cable \& Undersea Communications from the first submarine cable of 1850 to the worldwide fiber optic network. Available at http://atlantic-cable.com 26 July 2020.

Calvano E, Calzolari G, Denicoló V and Pastorello S (2019) Algorithmic pricing what implications for competition policy? Review of Industrial Organization 55, 155-171. Available at https://doi.org/10.1007/s11151-019-09689-3.

Cappitelli F and Sorlini C (2005) From papyrus to compact disc: The microbial deterioration of documentary heritage. Critical Reviews in Microbiology 31, 1-10. Available at http://dx.doi.org/10.1080/10408410490884766.

Carrasco-Torrontegui A, Gallegos-Riofrío CA, Delgado-Espinoza F and Swanson M (2020) Climate change, food sovereignty and ancestral farming technologies in the Andes. Current Developments in Nutrition, nzaa073. Available at https://doi.org/ 10.1093/cdn/nzaa073.

Castro D, McLaughlin M and Chivot E (2019) Who is winning the AI race: China, the EU or the United States? Center for Data Innovation, August 2019. Available at https:/www.datainnovation.org/2019/08/who-is-winning-the-ai-race-china-the-eu-orthe-united-states/.

Cerdas F, Juraschek M, Thiede S and Herrmann C (2017) Life cycle assessment of 3D printed products in a distributed manufacturing system. Journal of Industrial Ecology 21, S80-S93. Available at https://dx.doi.org/10.1111/jiec.12618.

Chao J (2012) Berkeley Lab seeks to help U.S. assert scientific leadership in critical materials, 11 January 2012. Available at http:// newscenter.lbl.gov/2012/01/11/critical-materials/.

Chatfield K, Borsella E, Mantovani E, Porcari A, and Stahl BC (2017) An investigation into risk perception in the ICT industry as a core component of responsible research and innovation. Sustainability 9,1424. Available at https://dx.doi.org/10.3390/ su9081424.

Chong B (2017) Introducing transfer appliance: Sneakernet for the cloud era. Google Could Platform Blog, 18 July 2017. Available at https://cloudplatform.googleblog.com/2017/07/introducing-Transfer-Appliance-Sneakernet-for-the-cloud-era.html.

Commission on Genetic Resources for Food and Agriculture (2019) The state of the world's biodiversity for food and agriculture. Technical report. Food and Agriculture Organization of the United Nations. Available at http://www.fao.org/ documents/card/en/c/ca3129en

Competition Authorities Working Group on Digital Economy (2019) BRICS in the digital economy. Competition policy in practice. Available at http://www.bricscompetition.org/materials/news/digital-era-competition-brics-report/.

Conant J and Fadem P (2008) A Community Guide to Environmental Health. Berkeley, CA: Hesperian Health Guides. Available at http://en.hesperian.org/hhg/A_Community_Guide_to_Environmental_Health.

Conner C (2019) When robots collude. Global Competition Review, 27 September 2019. Available at https:// globalcompetitionreview.com/insight/ger-q3-2019/1202826/when-robots-collude.

Conte T, DeBenedictis E, Ganesh N, Hylton T, Strachan JP, Williams RS, Alemi A, Altenberg L, Crooks G, Crutchfield J, del Rio L, Deutsch J, DeWeese M, Douglas K, Esposito M, Frank M, Fry R, Harsha P, Hill M, Kello C, Krichmar J, Kumar S, Liu S-C, Lloyd S, Marsili M, Nemenman I, Nugent A, Packard N, Randall D, Sadowski P, Santhanam N, Shaw R, Stieg A, Stopnitzky E, Teuscher C, Watkins C, Wolpert D, Yang J and Yufik Y (2019) Thermodynamic computing. A report based on a Computing Community Consortium (CCC) workshop held on January 3-5, 2019. arXiv:1911.01968 [cs.CY]. Available at https://arxiv.org/abs/1911.01968.

Coordination Nationale des Organisations Paysannes du Mali (CNOP), La Via Campesina (LVC), Movimiento Agroecológico de América Latina y el Caribe (MAELA), Réseau des organisations paysannes et de producteurs de l'Afrique de l'Ouest (ROPPA), World Forum of Fish Harvesters and Fishworkers (WFF), World Forum of Fisher Peoples (WFFP), World Alliance of Mobile Indigenous Peoples (WAMIP) and More and Better (MaB) (2015) Declaration of the International Forum for Agroecology, Nyéléni, Mali: 27 February 2015. Development 58, 163-168. Available at https://doi.org/10.1057/ s41301-016-0014-4.

Cordes C (2020) Cambridge Analytica showed us the dangers of "academic commercialism." What happens to ethics when universities rush to monetize their work? The Nation, 10 April 2020. Available at https://www.thenation.com/article/society/ cambridge-analytica-academic/.

Cornish C (2018) How DNA could store all the world's data in a semi-trailer. Financial Times, 5 February 2018. Available at https:// www.ft.com/content/45ea22b0-cec2-11e7-947e-flea5435bcc7.

Crawford K and Joler V (2018) Anatomy of an AI system. The Amazon Echo as an anatomical map of human labor, data and planetary resources. Available at https://anatomyof.ai/.

Croman K, Decker C, Eyal I, Gencer AF, Juels A, Kosba A, Miller A, Saxena P, Shi E, Sirer EG, Song D and Wattenhofer R (2016) On scaling decentralized blockchains. In Clark J, Meiklejohn S, Ryan P, Wallach D, Brenner M and Rohloff K (eds), Financial Cryptography and Data Security (FC 2016), pp. 106-125. Berlin, Germany: Springer Link. Available at https:// dx.doi.org/10.1007/978-3-662-53357-4_8. 
Daian P and Juels A (2017) The greening of blockchains. Hacking, Distributed, 23 February 2017. Available at http:// hackingdistributed.com/2017/02/23/green-blockchains/.

Dãno N and Prato S (2019) Editorial: The real technology revolution: Technology justice. Development 62, 1-4. Available at https://doi.org/10.1057/s41301-019-00230-3.

Davidson S, De Filippi P and Potts J (2018) Blockchains and the economic institutions of capitalism. Journal of Institutional Economics 14, 639-658. Available at https://doi.org/10.1017/S1744137417000200.

De Decker K (2014) How sustainable is digital fabrication? Low-Tech Magazine, 25 March 2014. Available at http://www lowtechmagazine.com/2014/03/how-sustainable-is-digital-fabrication.html.

De Decker K. (2016) The curse of the modern office. DEMAND. Dynamics of Energy, Mobility and Demand, 22 November 2011. Available at http://www.demand.ac.uk/22/11/2016/the-curse-of-the-modern-office/.

De Decker K (2018) Bedazzled by energy efficiency. Low-Tech Magazine, 09 January 2018. Available at http://www. lowtechmagazine.com/2018/01/bedazzled-by-energy-efficiency.html.

de Groot J (2018) The libraries of the future will be made of DNA. The Conversation, 5 January 2018. Available at http:// theconversation.com/the-libraries-of-the-future-will-be-made-of-dna-86274.

De Silva PY and Ganegoda GU (2016) New trends of digital data storage in DNA. BioMed Research International 2016, 8072463. Available at https://dx.doi.org/10.1155/2016/8072463.

De Decker K (2007) Email in the 18th century: The optical telegraph. Low-Tech Magazine, 23 December 2007. Available at http:// www.lowtechmagazine.com/2007/12/email-in-the-18.html.

De Decker K (2009) The monster footprint of digital technology. Low-Tech Magazine, 16 June 2009. Available at http://www. lowtechmagazine.com/2009/06/embodied-energy-of-digital-technology.html.

De Decker K (2015) How to build a low-tech internet. Low-Tech Magazine, 26 October 2015. Available at http://www. lowtechmagazine.com/2015/10/how-to-build-a-low-tech-internet.html.

De Decker K (2015) Why we need a speed limit for the internet. Low-Tech Magazine, 19 October 2015. Available at http:/ www.lowtechmagazine.com/2015/10/can-the-internet-run-on-renewable-energy.html.

De Decker K (2018) How much energy do we need? Low-Tech Magazine, 24 January 2018. Available at http://www. lowtechmagazine.com/2018/01/how-much-energy-do-we-need.html.

Deisenroth M, Mohamed S, Doshi-Velez F, Krause A and Welling M (2016) ICML 2016 Workshop on Data-Efficient Machine Learning. Available at https://sites.google.com/site/dataefficientml/.

Deng A (2019) From the dark side to the bright side: Exploring algorithmic antitrust compliance. Social Sciences Research Network. Available at http://dx.doi.org/10.2139/ssrn.3334164.

Department for Business, Energy \& Industrial Strategy (2017) Industrial strategy: Building a Britain fit for the future. Technical report. HM Government. Available at https://www.gov.uk/government/uploads/system/uploads/attachment_data/file/662508/ industrial-strategy-white-paper.pdf.

Devitt SJ, Greentree AD, Stephens AM and Van Meter R (2016) High-speed quantum networking by ship. Scientific Reports 6 , 36163. Available at https://dx.doi.org/10.1038/srep36163.

Donovan KP and Park E (2019) Perpetual debt in silicon Savannah. Boston Review, 20 September 2019. Available at http:/ bostonreview.net/class-inequality-global-justice/kevin-p-donovan-emma-park-perpetual-debt-silicon-savannah.

Dunlap A (2019) Green New Deal Part II: Good, bad \& the ugly. Terra Nullius: Re-Possessing the Existent, 11 November 2019. Available at https://www.sum.uio.no/forskning/blogg/terra-nullius/green-new-deal-part-II-good-bad-and-the-ugly.html.

Dürrenmatt, F (2006) The Physicists, A Comedy in Two Acts. Chicago, IL: University of Chicago Press. Available at http:// www.press.uchicago.edu/ucp/books/book/chicago/F/bo4108421.html.

Dutta AK and Hasan R (2013) How much does storage really cost? Towards a full cost accounting model for data storage. In Altmann J, Vanmechelen K and Rana OF (eds), Economics of Grids, Clouds, Systems, and Services (GECON 2013), pp. $29-43$. Cham, Switzerland: Springer Link. Available at https://dx.doi.org/10.1007/978-3-319-02414-1_3.

Dutton T (2018) An overview of national AI strategies. Medium, 29 June 2018. Available at https://medium.com/politics-ai/anoverview-of-national-ai-strategies-2a70ec6edfd.

Eastwood C, Klerkx L, Ayre M and Dela Rue B (2017) Managing socio-ethical challenges in the development of smart farming: From a fragmented to a comprehensive approach for responsible research and innovation. Journal of Agricultural and Environmental Ethics 32, 741-768. Available at https://doi.org/10.1007/s10806-017-9704-5.

Electronics Takeback Coalition (n.d.). Take it back. Make it green. Recycle responsibly. Available at http://www.electronicstakeback. com 26th July 2020.

Ellis AD, Mac Suibhne N, Saad D and Payne DN (2016) Communication networks beyond the capacity crunch. Philosophical Transactions of the Royal Society A 374, 20150191. Available at http://dx.doi.org/10.1098/rsta.2015.0191.

Engin Z (2018) Digital ethics: Data, algorithms, interactions. Zenodo. Available at https://doi.org/10.5281/zenodo.1481833.

Engineering and Physical Sciences Research Council (EPSRC) (n.d.) Frameworkfor responsible innovation. Available at http:// www.epsrc.ac.uk/research/framework/ 26 July 2020.

Engineering and Physical Sciences Research Council (EPSRC) (n.d.) Anticipate, reflect, engage and act (AREA). Available at https://www.epsrc.ac.uk/research/framework/area/ 26 July 2020.

European Union (n.d.) ProGReSS (PROmoting Global REsponsible research and Social and Scientific innovation). Available at https://cordis.europa.eu/project/id/32140026 July 2020. 
Evans D (2011) The Internet of Things: How the next evolution of the internet is changing everything. Cisco Internet Business Solutions Group. Available at http://www.cisco.com/web/about/ac79/docs/innov/IoT_IBSG_0411FINAL.pdf.

Extance A (2016) How DNA could store all the world's data. Nature 537, 22-24. Available at https://dx.doi.org/10.1038/537022a.

Extance A (2017) Could Bitcoin technology help science? Nature 552, 301-302. Available at https://doi.org/10.1038/d41586-01708589-4.

Van Eygen E, De Meester S, Tran HP and Dewulf J (2016) Resource savings by urban mining: The case of desktop and laptop computers in Belgium. Resources, Conservation and Recycling 107, 53-64. Available at https://doi.org/10.1016/j. resconrec.2015.10.032.

Eyres H (2020) How coronavirus has led to the return of the precautionary principle. New Statesman, 7 April 2020. Available at https://www.newstatesman.com/international/2020/04/how-coronavirus-has-led-return-precautionary-principle.

Fairley P (2017) The ridiculous amount of energy it takes to run Bitcoin. IEEE Spectrum, 28 September 2017. Available at https:// spectrum.ieee.org/energy/policy/the-ridiculous-amount-of-energy-it-takes-to-run-bitcoin.

Fibershed (n.d.) Our mission \& vision. Fibershed develops regional and regenerative fiber systems on behalf of independent working producers. Available at http://www.fibershed.com/about/ 26 July 2020.

Fitzpatrick C, Olivetti E, Miller TR, Roth R and Kirchain R (2015) Conflict minerals in the compute sector: Estimating extent of tin, tantalum, tungsten, and gold use in ICT products. Environmental Science \& Technology 49, 974-981. Available at http:// dx.doi.org/10.1021/es501193k.

Floridi L and Cowls J (2019) A unified framework of five principles for AI in society. Harvard Data Science Review, 1. Available at https://dx.doi.org/10.1162/99608f92.8cd550d1.

Food and Agriculture Organization of the United Nations (2015) International year of soils 2015. Healthy soils for a healthy life. Available at http://www.fao.org/soils-2015/en/.

Gallego-Schmid A, Mendoza JMF and Azapagic A (2018) Environmental assessment of microwaves and the effect of European energy efficiency and waste management legislation. Science of the Total Environment 618, 487-499. Available at https://doi.org/ 10.1016/j.scitotenv.2017.11.064.

Gatteschi V, Lamberti F, Demartini C, Pranteda C and Santamaría V (2018) Blockchain and smart contracts for insurance: Is the technology mature enough? Future Internet 10, 1-16. Available at http://dx.doi.org/10.3390/fi10020020.

Geyer R, Jambeck JR and Law KL (2017) Production, use, and fate of all plastics ever made. Science Advances 3, e1700782. Available at https://dx.doi.org/10.1126/sciadv.1700782.

Giampietro G and Mayumi K (2018) Unraveling the complexity of the Jevons paradox: The link between innovation, efficiency, and sustainability. Frontiers in Energy Research 6, 26. Available at https://doi.org/10.3389/fenrg.2018.00026.

Giannella E (2015) Morality and the idea of progress in Silicon Valley. Berkeley Journal, 14 January 2015. Available at http:/ berkeleyjournal.org/2015/01/morality-and-the-idea-of-progress-in-silicon-valley/.

Gilbert S and Lynch N (2002) Brewer's conjecture and the feasibility of consistent available partition-tolerant web services. $A C M$ SIGACT News 33, 51-59. Available at https://doi.org/10.1145/564585.564601.

Giles M, Hetherington JPJ, Montana G, Armour WG, Bush I, Sandler M, Gray A, Richmond P, Trefethen AE, Cox SJ, McIntosh-Smith S and Timm DA (2016) The Joint Academic Data Science Endeavour (JADE) High Performance Computing (HPC) UK, supporting world-leading research in machine learning. Available at http:/www.jade.ac.uk/.

Giungato P, Rana R, Tarabella A and Tricase C (2017) Current trends in sustainability of Bitcoins and related blockchain technology. Sustainability 9, 2214. Available at https://doi.org/10.3390/su9122214.

Gmach D, Chen Y, Shah A, Rolia J, Bash C, Christian T and Sharma R (2010) Profiling sustainability of data centers. In International Symposium for Sustainable Systems and Technology (ISSST), pp. 1-6. IEEE. Available at https://doi.org/10.1109/ ISSST.2010.5507750.

Gonzalez-Sanchez MB, Lopez-Valeiras E and García-Montero AC (2014) Implementation of a cost-accounting model in a biobank: Practical implications. Pathobiology 81, 286-297. Available at https://dx.doi.org/10.1159/000362796.

Tapia Granados JA, Ionides EL and Carpintero O (2012) Climate change and the world economy: Short-run determinants of atmospheric $\mathrm{CO}_{2}$. Environmental Science \& Policy 21, 50-62. Available at https://doi.org/10.1016/j.envsci.2012.03.008.

Gurumurthy A and Chami N (2019) Development justice in the digital paradigm: Agenda 2030 and beyond. Development 62, 19-28. Available at https://doi.org/10.1057/s41301-019-00203-6

Gurzu A (2017) Smart energy stumped by "rebound effect". Politico EU, 24 May 2017. Available at https://www.politico.eu/ article/smart-energy-stumped-by-rebound-effect/.

Guttieres D (2019) An intra- and inter-generational lens into rapid technological change. Development 62, 37-42. Available at https://doi.org/10.1057/s41301-019-00220-5.

Handley M, Raiciu C, Agache A, Voinescu A, Moore AW, Antichi G and Wócik M (2017) Re-architecting datacenter networks and stacks for low latency and high performance. In SIGCOMM '17: Proceedings of the Conference of the ACM Special Interest Group on Data Communication, pp. 29-42. Available at https://doi.org/10.1145/3098822.3098825.

Hanieh S, High H and Boulton J (2020) Nutrition justice: Uncovering invisible pathways to malnutrition. Frontiers in Endocrinology 11, 150. Available at https://doi.org/10.3389/fendo.2020.00150.

Hankey S and Tuszynski M (2017) Efficiency and Madness - Using Data and Technology to Solve Social, Environmental and Political Problems. Heinrich Böll Foundation, Germany 28 November 2017. Available at https://www.boell.de/en/2017/11/28/ efficiency-and-madness-using-data-and-technologyto-solve-social-environmental-and-political-problems. 
Harkinson J (2015) Scores of scientists raise alarm about the long-term health effects of cellphones. Mother Jones Magazine, 11 May 2015. Available at http://www.motherjones.com/environment/2015/05/cellphone-emf-wifi-health-risks-scientists-letter.

Heckel H, Mikutis G and Grass RN (2019) A characterization of the DNA data storage channel.Sci Rep 9, 9663. Available at https://doi.org/10.1038/s41598-019-45832-6.

Heckel R (2018) An archive written in DNA. Nature Biotechology 36, 236-237. Available at https://www.nature.com/articles/ nbt.4093.

Heckel R, Shomorony I, Ramachandran K and Tse DNC (2017) Fundamental limits of DNA storage systems. In 2017 IEEE International Symposium on Information Theory (ISIT). Available at https://doi.org/10.1109/ISIT.2017.8007106.

Hileman G and Rauchs M (2017) 2017 Global Cryptocurrency Benchmarking Study. Social Sciences Research Network. Available at http://dx.doi.org/10.2139/ssrn.2965436.

Ho C (2018) Data storage on DNA: Where Silicon Valley meets biotech. San Franciso Chronicle, 12 March 2018. Available at https://www.sfchronicle.com/business/article/Data-storage-on-DNA-Where-Silicon-Valley-meets-12739841.php.

Holmes C (2017) Distributed ledger technologies for public good: Leadership, collaboration and innovation. House of Lords. Available at http://chrisholmes.co.uk/wp-content/uploads/2017/11/Distributed-Ledger-Technologies-for-Public-Good_leader ship-collaboration-and-innovation.pdf. http://chrisholmes.co.uk/blog/tech-opportunity-carpe-dlt/.

Holmes S (2020) Climate change, sustainability, and competition law. Journal of Antitrust Enforcement 8, 354-405. Available at https://doi.org/10.1093/jaenfo/jnaa006.

Hormann P and Campell L (2014) Data storage energy efficiency in the zettabyte era. Australian Journal of Telecommunications and the Digital Economy, 2. Available at http://doi.org/10.7790/ajtde.v2n3.51.

Horton R (2017) Offline: Planetary health's next frontier-Biodiversity. The Lancet 390, 2132. Available at http://dx.doi.org/ 10.1016/S0140-6736(17)32843-X.

Howell S (2019) Detroit targeted for massive facial surveillance. Black Agenda Report, 17 July 2019. Available at https:/ www.blackagendareport.com/detroit-targeted-massive-facial-surveillance.

Hull R (2017) Blockchain: Distributed event-based processing in a data-centric world: Extended abstract. In ACM International Conference on Distributed and Event-Based Systems, pp. 2-4. Available at https://doi.org/10.1145/3093742.3097982.

Intel Developer Zone (2017) Platform and Technology Discussion Forum. Intel ISA Extensions. Available at https://software. intel.com/en-us/forums/intel-isa-extensions/topic/710250.

ITU, XPRIZE Foundation, 37 United Nations agencies, and ACM (n.d.) AI for Good Global Series. The leading action-oriented, global \& inclusive United Nations platform on AI. International Telecommunications Unit. Available at https://aiforgood.itu.int/ about-us/ 26th July 2020.

James D (2019) Anti-development impacts of tax-related provisions in proposed rules on digital trade in the WTO. Development 62, 58-65. Available at https://doi.org/10.1057/s41301-019-00205-4.

Jevons WS (1865) The Coal Question: An Inquiry Concerning the Progress of the Nation, and the Probable Exhaustion of Our Coal-Mines. New York, NY: A. M. Kelley. Available at https://archive.org/details/coalquestionani00jevogoog.

Jordan S, Fazelpour S, Koshiyama A, Kueper J, DeChant C, Leong B, Marchant G and Shank C (2019) Creating a tool to reproducibly estimate the ethical impact of artificial intelligence. Program on Understanding Law, Science, and Evidence (PULSE) at UCLA School of Law. Available at https://aipulse.org/creating-a-tool-to-reproducibly-estimate-the-ethical-impactof-artificial-intelligence/.

Joseph A (2020) Everything we know about coronavirus immunity and antibodies - and plenty we still don't. Stat News, 20 April 2020. Available at https://www.statnews.com/2020/04/20/everything-we-know-about-coronavirus-immunity-and-antibodiesand-plenty-we-still-dont/.

Joshi AP, Han M and Wang Y (2018) A survey on security and privacy issues of blockchain technology. Mathematical Foundations of Computing 1, 121-147. Available at http://dx.doi.org/10.3934/mfc.2018007.

Judge P (2016) The truth is: Data center power is out of control. Datacenter Dynamics, 12 January 2016. Available at http:// www.datacenterdynamics.com/content-tracks/design-build/the-truth-is-data-center-power-is-out-of-control/95425.fullarticle.

Kakushadze Z and Russo Jr RP (2018) Blockchain: Data malls, coin economies and keyless payments. The Journal of Alternative Investments 21, 8-16. Available at https://dx.doi.org/10.2139/ssrn.3104745.

Kennedy E, Raiten D and Finley J (2020) A view to the future: Opportunities and challenges for food and nutrition sustainability. Current Developments in Nutrition 4, nzaa035. Available at https://doi.org/10.1093/cdn/nzaa035.

Kolinjivadi V (2019) Why a hipster, vegan, green tech economy is not sustainable. Al-Jazeera, 6 June 2019. Available at https:// www.aljazeera.com/indepth/opinion/hipster-vegan-green-tech-economy-sustainable-190605105120654.html.

Koshiyama A and Engin Z (2019) Algorithmic impact assessment: Fairness, robustness and explainability in automated decisionmaking. Zenodo. Available at https://doi.org/10.5281/zenodo.3241852.

Kuehr, R (2014) Solving the E-waste Problem (StEP) White Paper: One Global Definition of E-waste. United Nations University. Available at https://collections.unu.edu/view/UNU:6120.

Kusch S and Hills CD (2017) The link between e-waste and GDP-New Insights from data from the pan-European region. Resources 2,15. Available at http://dx.doi.org/10.3390/resources6020015.

Lago P, Akinli Koçak S, Crnkovic I and Penzenstadler B (2015) Framing sustainability as a property of software quality. Communications of the ACM 58, 70-78. Available at http://dx.doi.org/10.1145/2714560.

LaMonica M (2014) The spiralling energy consumption behind your smart phone. The Guardian, 10 September 2014. Available at http://www.theguardian.com/sustainable-business/2014/sep/10/energy-consumption-behind-smart-phone. 
Landrigan PJ, Fuller R, Acosta NJR, Adeyi O, Arnold R, Basu NN, Baldé AB, Bertollini R, Bose-O'Reilly S, Boufford JI, Breysse PN, Chiles T, Mahidol C, Coll-Seck AM, Cropper ML, Fobil J, Fuster V, Greenstone M, Haines A, Hanrahan D, Hunter D, Khare M, Krupnick A, Lanphear B, Lohani B, Martin K, Mathiasen KV, McTeer MA, Murray CJL, Ndahimananjara JD, Perera F, Potočnik J, Preker AS, Ramesh J, Rockström J, Salinas C, Samson LD, Sandilya K, Sly PD, Smith KR, Steiner A, Stewart RB, Suk WA, van Schayck OCP, Yadama GN, Yumkella K and Zhong M(2018) The Lancet Commission on pollution and health. The Lancet 391, 462-512. Available at https://doi.org/10.1016/S0140-6736(17) 32345-0.

Lázaro A, Chroni A, Tscheulin T, Devalez J, Matsoukas C and Petanidou T (2016) Electromagnetic radiation of mobile telecommunication antennas affects the abundance and composition of wild pollinators. Journal of Insect Conservation 20, 315-324. Available at https://doi.org/10.1007/s10841-016-9868-8.

Lee EA (2015) The past, present and future of cyber-physical systems: A focus on models. Sensors 15, 4837-4869. Available at https://doi.org/10.3390/s150304837.

Lenz A, Siegel PH, Wachter-Zeh A and Yaakobi E (2020) Coding over sets for DNA storage. IEEE Trans Inf Theory 66, 23312351. Available at https://doi.org/10.1109/TIT.2019.2961265.

Leonelli S (2019) Data-From objects to assets. Nature 574, 317-320. Available at https://doi.org/10.1038/d41586-019-03062-w.

Levine Y (2018) Surveillance Valley: The Secret Military History of the Internet. Public Affairs, U.S.A.. Available at https:// surveillancevalley.com/.

Lianos I (2019) Competition law for a complex economy. International Review of Intellectual Property and Competition Law 50, 643-648. Available at https://doi.org/10.1007/s40319-019-00829-6.

Liboiron M (2018) How plastic is a function of colonialism. Teen Vogue, 21 December 2018. Available at https://www.teenvogue. $\mathrm{com} /$ story/how-plastic-is-a-function-of-colonialism.

Lima JM (2018) The next chapter. How DNA storage will transform data centre design beyond recognition. Data Economy, 12 February 2018. Available at https://data-economy.com/next-chapter-dna-storage-will-transform-data-centre-design-beyondrecognition/.

Liu M, Huang B, Bi X, Ren Z, Sheng G and Fu J (2013) Heavy metals and organic compounds contamination in soil from an e-waste region in South China. Environmental Science: Processes \& Impacts 15, 919-929. Available at https://doi.org/10.1039/ c3em00043e.

Lohmann L (2019) Labour, justice and the mechanization of interpretation. Development 62, 43-52. Available at https://doi.org/ 10.1057/s41301-019-00207-2.

Lohmann L and Hildyard N (2019) The museum of fetishes. Development 62, 103-110. Available at https://doi.org/10.1057/ s41301-019-00215-2.

Lynch J and Demaine E (2014) Faster, cheaper, cooler, longer: Energy efficient algorithms. MADALGO: Center for Massive Data Algorithmics, a Center of the Danish National Research Foundation. Available at http://www.cs.au.dk/ gerth/madalgo/posters/ 13/pdf/jayson.pdf.

MacKay D (2009) Sustainability Energy—Without the Hot Air. Cambridge, UK: UIT. Available at https://www.withouthotair.com/.

Magee CL and Devezas TC (2017) A simple extension of dematerialization theory: Incorporation of technical progress and the rebound effect. Technological Forecasting and Social Change 117, 196-205. Available at https://doi.org/10.1016/j techfore.2016.12.001.

Malanov A (2017) Six myths about blockchain and Bitcoin: Debunking the effectiveness of the technology. Kaspersky Daily, 18 August 2017. Available at https://www.kaspersky.com/blog/bitcoin-blockchain-issues/18019/.

Marcus G (2019) An epidemic of AI misinformation. The Gradient, 30 November 2019. Available at https://thegradient.pub/anepidemic-of-ai-misinformation/.

Markov IL (2014) Limits on fundamental limits to computation. Nature 512, 147-154. Available at http://dx.doi.org/10.1038/ nature 13570 .

Martin A (2018) Alexa will soon take up a pointless residence in your microwave. Alphr, 5 January 2018. Available at http:// www.alphr.com/amazon/1008103/alexa-will-soon-take-up-a-pointless-residence-in-your-microwave.

Mateos-Garcia J (2020) The economics of AI today. The Gradient, 18 January 2020. Available at https://thegradient.pub/theeconomics-of-ai-today/.

Matlack S (2012) The physicists at fifty. The New Atlantis No. 36, 63-78. Available at http://www.thenewatlantis.com/publications/ the-physicists-at-fifty.

McQuillan D (2018) People's councils for ethical machine learning. Social Media + Society 4, 1-10. Available at https://dx.doi.org/ $10.1177 / 2056305118768303$.

McWilliams B and Zachmann G (2020) Covid-19 crisis: Electricity demand as a real-time indicator. Bruegel, 25 March 2020. Available at https://www.bruegel.org/2020/03/covid-19-crisis-electricity-demand-as-a-real-time-indicator/.

Meiklejohn S (2018) Top ten obstacles along distributed ledgers' path to adoption. IEEE Security \& Privacy Magazine 16, 13-19. Available at https://doi.org/10.1109/MSP.2018.3111235.

Mendling J, Weber I, Van Der Aalst W, Vom Brocke J, Cabanillas C, Daniel F, Debois S, Di Ciccio C, Dumas M, Dustdar S, Gal A, García-Bañuelos L, Governatori G, Hull R, La Rosa M, Leopold H, Leymann F, Recker J, Reichert M, Reijers HA, Rinderle-Ma S, Solti A, Rosemann M, Schulte S, Singh MP, Slaats T, Staples M, Weber B, Weidlich M, Weske M, Xu X and Zhu L (2018) Blockchains for business process management-Challenges and opportunities. In ACM Transactions on Management Information Systems (TMIS) Vol. 9, pp. 4.1-4.16. Available at https://doi.org/10.1145/3183367. 
Merchant C (2006) The scientific revolution and the death of nature. Isis 972, 513-533. Available at http://nature.berkeley.edu/ departments/espm/env-hist/articles/84.pdf.

Merlo A, Migliardi M and Caviglione L (2015) A survey on energy-aware security mechanisms. Pervasive and Mobile Computing 24, 77-90. Available at http://dx.doi.org/10.1016/j.pmcj.2015.05.005.

Mian IS and Rose C (2011) Communication theory and multicellular biology. Integrative Biology 3, 350-367. Available at http:// dx.doi.org/10.1039/c0ib00117a.

Mietchen D, Schwaiger V and Beyan O (2019) FAIR ethics: Making ethical review processes more machine actionable. Research Data Alliance (RDA) 12th Plenary. Available at https://doi.org/10.5281/zenodo.2559997.

Mignolo W (2011) The Darker Side of Western Modernity: Global Futures, Decolonial Options. Durham, NC: Duke University Press. Available at https://www.dukeupress.edu/The-Darker-Side-of-Western-Modernity.

Mirzayi S and Mehrzad M (2017) Bitcoin, an SWOT analysis. In International Conference on Computer and Knowledge Engineering (ICCKE). Available at https://doi.org/10.1109/ICCKE.2017.8167876.

MIT Solving Complex Problems (2012) Mission 2016: Strategic mineral management. Available at http://web.mit.edu/12.000/ www/m2016/finalwebsite/index.html.

Mittelstadt B (2019) Principles alone cannot guarantee ethical AI. Nature Machine Intelligence 1, 501-507. Available at https:// dx.doi.org/10.1038/s42256-019-0114-4.

Moberg E, Karlsson Potter H, Wood A, Hansson P-A and Röös E (2020) Benchmarking the Swedish diet relative to global and national environmental targets-Identification of indicator limitations and data gaps. Sustainability 12, 1407. Available at https:// doi.org/10.3390/su12041407.

Monroe D (2016) Optical fibers are getting full. Communications of the ACM 59, 10-12. Available at https://doi.org/10.1145/ 2983268.

Mooney P (2018) Blocking the chain. Industrial food chain concentration, Big Data platforms and food sovereignty solutions. Available at https://www.etcgroup.org/content/blocking-chain.

Moore J (2019) AI for not bad. Frontiers in Big Data 2, 32. Available at https://doi.org/10.3389/fdata.2019.00032.

Morozov E (2013) To Save Everything, Click Here: The Folly of Technological Solutionism. Public Affairs, U.S.A.. Available at https://www.publicaffairsbooks.com/titles/evgeny-morozov/to-save-everything-click-here/9781610391399/.

Morozov E (2017) Digital intermediation of everything: At the intersection of politics, technology and finance. In 4th Council of Europe Platform Exchange on Culture and Digitisation. Empowering Democracy Through Culture - Digital Tools for Culturally Competent Citizens. Available at https://rm.coe.int/digital-intermediation-of-everything-at-the-intersection-of-politics-t/ 168075 baba.

Morozov E (2020) The tech "solutions" for coronavirus take the surveillance state to the next level. The Guardian, 15 April 2020 Available at https:/www.theguardian.com/commentisfree/2020/apr/15/tech-coronavirus-surveilance-state-digital-disrupt.

Moss S (2017) Microsoft soft launches 100TB Azure Data Box, its take on Sneakernet. Datacenter Dynamics. The Business of Data Centers. Available at http://www.datacenterdynamics.com/content-tracks/colo-cloud/microsoft-soft-launches-100tb-azuredata-box-its-take-on-sneakernet/99019.fullarticle.

Muelhlhauser L (2014) Erik DeBenedictis on supercomputing. Machine Learning Research Institute. Available at https:// intelligence.org/2014/04/03/erik-debenedictis/.

Mueller S, Jafari F and Roth D (2016) A covert authentication and security solution for GMOs. BMC Bioinformatics $17,389$. Available at https://doi.org/10.1186/s12859-016-1256-6.

Mulvany P (2014) Agricultural biodiversity, ecological food provision and food sovereignty: Vital interdependencies. In Food Sovereignty: A Critical Dialogue. The Hague, The Netherlands: International Institute of Social Studies (ISS). Available at https://www.iss.nl/sites/corporate/files/94_Mulvany.pdf.

Murugesan S (2008) Harnessing green IT: Principles and practices. IT Professional 10, 24-33. Available at http://dx.doi.org/ 10.1109/MITP.2008.10.

Nakano T (2017) Molecular communication: A 10 year retrospective. IEEE Transactions on Molecular, Biological and Multi-Scale Communications 3, 71-78. Available at https://dx.doi.org/10.1109/TMBMC.2017.2750148.

Nandy A (ed.) (1988) Science, Hegemony and Violence. Oxford, UK: Oxford University Press. Available at https://archive.org/ details/ScienceHegemonyAndViolenceARequiemForModernity.

Nardi B, Tomlinson B, Patterson DJ, Chen J, Pargman D, Raghavan B and Penzenstadler B (2018) Computing within limits. Communications of the ACM 61, 86-93. Available at https://dx.doi.org/10.1145/3183582.

National Institute Standards and Technology Engineering Laboratory (n.d.) Cyber-physical systems. Available at https:// www.nist.gov/el/cyber-physical-systems.

Neiman MS (1964) Some fundamental issues of microminiaturization. Radiotekhnika pp. 3-12. Available at https://sites.google. com/site/msneiman1905/eng.

Newcombe L (2008) Data centre energy efficiency metrics. Existing and proposed metrics to provide effective understanding and reporting of data centre energy. Available at https://www.bcs.org/media/2916/data-centre-energy_1.pdf.

Ney P, Koscher K, Organick L, Ceze L and Kohno T (2017) Computer security, privacy, and DNA sequencing: Compromising computers with synthesized DNA, privacy leaks, and more. In 26th USENIX Security Symposium (USENIX Security 17), pp. 765-779. Available at https://www.usenix.org/conference/usenixsecurity17/technical-sessions/presentation/ney.

Niranjanamurthy M, Nithya BN and Jagannatha S (2018) Analysis of blockchain technology: Pros, cons and SWOT. Cluster Computing 22, 14743-14757. Available at https://doi.org/10.1007/s10586-018-2387-5. 
Notter DA, Meyer R and Althaus H-J (2013) The Western lifestyle and its long way to sustainability. Environmental Science \& Technology 47, 4014-4021. Available at http://dx.doi.org/10.1021/es3037548.

O'Neil C (2017) The era of blind faith in big data must end. TED Talk. Available at https://www.ted.com/talks/cathy_o_neil_the_ era_of_blind_faith_in_big_data_must_end/transcript?language=en.

Ochigame R (2019) The invention of "ethical AI." How big tech manipulates academia to avoid regulation. The Intercept, 20 December 2019. Available at https://theintercept.com/2019/12/20/mit-ethical-ai-artificial-intelligence/.

Organick L, Ang SD, Chen YJ, Lopez R, Yekhanin S, Makarychev K, Racz MZ, Kamath G, Gopalan P, Nguyen B, Takahashi CN, Newman S, Parker HY, Rashtchian C, Stewart K, Gupta G, Carlson R, Mulligan J, Carmean D, Seelig G, Ceze L and Strauss K (2018) Random access in large-scale DNA data storage. Nature Biotechnology 362, 242-248. Available at https://doi.org/10.1038/nbt.4079.

Parker W and Ollerton J (2013) Evolutionary biology and anthropology suggest biome reconstitution as a necessary approach toward dealing with immune disorders. Evolution, Medicine, and Public Health 1, 89-103. Available at http://dx.doi.org/ 10.1093/emph/eot008.

Parks L and Starosielski N (eds.) (2015) Signal Traffic. Critical Studies of Media Infrastructures. Chicago, IL: University of Illinois Press. Available at http://www.press.uillinois.edu/books/catalog/26bxm4qd9780252039362.html.

Peccoud J, Gallegos JE, Murch R, Buchholz WG and Raman S (2018) Cyberbiosecurity: From naive trust to risk awareness. Trends in Biotechnology 362, 4-7. Available at https://doi.org/10.1016/j.tibtech.2017.10.012.

Pencheon D and Wight J (2020) Making healthcare and health systems net zero. BMJ 368, m970. Available at https://dx.doi.org/ 10.1136/bmj.m970.

Peng T (2016) Analysis of energy utilization in 3D printing processes. Procedia CIRP 40, 62-67. Available at https://doi.org/ 10.1016/j.procir.2016.01.055.

Pérez-Belis V, Bovea M and Ibáñez-Forés V (2015) An in-depth literature review of the waste electrical and electronic equipment context: Trends and evolution. Waste Management \& Research 33, 3-29. Available at http://dx.doi.org/10.1177/ $0734242 \mathrm{X} 14557382$.

Perry TS (2017) Nvidia wants AI to get out of the cloud and into a camera, drone, or other gadget near you. IEEE Spectrum, 8 March 2017. Available at https://spectrum.ieee.org/view-from-the-valley/computing/embedded-systems/nvidia-wants-ai-to-get-outof-the-cloud-into-a-camera-drone-or-other-gadget-near-you.

Phillips AM and Mian IS (2019) Governance and assessment of future spaces: A discussion of some issues raised by the possibilities of human-machine mergers. Development 62, 66-80. Available at https://doi.org/10.1057/s41301-019-00208-1.

Piccirillo C (2011) Environmental impact of information and communication technology. Available at http://www.decodedscience. com/environmental-impact-of-information-and-communication-technology/7453.

Qiu JL (2016) Goodbye iSlave: A Manifesto for Digital Abolition. Champaign, IL: University of Illinois Press. Available at http:// www.press.uillinois.edu/books/catalog/77shx5qp9780252040627.html.

Raff E (2020) Quantifying independently reproducible machine learning. The Gradient, 6 February 2020. Available at https:// thegradient.pub/independently-reproducible-machine-learning/.

Raghavan C (2018) Trust limitations of crypto-currencies \& potential ecological disaster. Third World Network, 20 June 2018. Available at https://www.twn.my/title2/finance/2018/fi180605.htm.

Ribeiro S (2019) Surfing the technological tsunami: The need for participatory technology assessment. Development 62, 111-115. Available at https://doi.org/10.1057/s41301-019-00210-7.

Rook GAW, Raison CL and Lowry CA (2014) Microbial 'old friends', immunoregulation and socioeconomic status. Clinical and Experimental Immunology 177, 1-12. Available at http://dx.doi.org/10.1111/cei.12269.

Rose C, Mian IS and Ozmen M (2019) Capacity bounds on point-to-point communication using molecules. Proceedings of the IEEE 107, 1342-1355. Available at https://doi.org/10.1109/JPROC.2019.2909503.

Rose C and Wright G. (2004) Inscribed matter as an energy-efficient means of communication with an extraterrestrial civilization. Nature 431, 47-49. Available at https://doi.org/10.1038/nature02884.

Rosenthal D (2014) Talk at Digital Preservation 2013, July 2013. Available at http://blog.dshr.org/2013/07/talk-at-digitalpreservation-2013.html.

Rosenthal D (2015) The evanescent web. DSHR's Blog, 10 February 2015. Available at http://blog.dshr.org/2015/02/the-evanes cent-web.html.

Rosenthal D (2017) Rick Whitt on digital preservation. DSHR's Blog, 25 January 2017. Available at https://blog.dshr.org/2017/01/ rick-whitt-on-digital-preservation.html.

Royal Academy of Engineering (n.d.) Engineering ethics and the academy. Available at https://www.raeng.org.uk/policy/ engineering-ethics/ethics 26th July 2020.

Rucevska I, Nellemann C, Isarin N, Yang W, Liu N, Yu K, Sandnaes S, Olley K, McCann H, Devia L, Bisschop L, Soesilo D, Schoolmeester T, Henriksen R and Nilsen R (2015) Waste crime-waste risks: Gaps in meeting the global waste challenge. A UNEP Rapid Response Assessment. United Nations Environment Programme and GRID-Arendal, Nairobi and Arendal. Available at https://www.grida.no/publications/166.

Ruzzenenti F, Wagner A, Sorrell SR, Galvin R, Vivanco DF and Walnum HJ (2018) The rebound effect and the Jevon's paradox: Beyond the conventional wisdom. Frontiers in Energy 7, 1-2. Available at https://dx.doi.org/10.3389/ fenrg.2019.00090. 
Saberi S, Kouhizadeh M and Sarkis J (2018) Blockchain technology: A panacea or pariah for resources conservation and recycling? Resources, Conservation and Recycling 130, 80-81. Available at https://www.sciencedirect.com/science/article/pii/ S0921344917304111.

Sadowski J (2019) When data is capital: Datafication, accumulation, and extraction. Big Data \& Society 6, 1-12. Available at https://dx.doi.org/10.1177/2053951718820549.

Santarius T (2017) Digitalization, efficiency and the rebound effect. Degrowth, 16 February 2017. Available at https://www. degrowth.info/en/2017/02/digitalization-efficiency-and-the-rebound-effect/.

Schuftan C, Legge D, Sanders D and Nadimpally S (2014) A manifesto for planetary health. The Lancet 383, 1459-1460. Available at https://doi.org/10.1016/S0140-6736(14)60710-8.

Schwab K (2016a) The Fourth Industrial Revolution. Penguin Random House. Available at https://www.penguinrandomhouse. com/books/551710/the-fourth-industrial-revolution-by-klaus-schwab/.

Schwab K (2016) The Fourth Industrial Revolution: What it means, how to respond. World Economic Forum, 14 January 2016. Available at https://www.weforum.org/agenda/2016/01/the-fourth-industrial-revolution-what-it-means-and-how-to-respond/.

Schwalbe U (2018) Algorithms, machine learning, and collusion. Journal of Competition Law \& Economics 14, $568-607$. Available at https://doi.org/10.1093/joclec/nhz004.

Schwartz R, Dodge J, Smith NA and Etzioni O (2019) Green AI. arXiv:1907.10597 [cs.CY]. Available at https://arxiv.org/abs/ 1907.10597.

Shanbhag NR (2016) Energy-efficient machine learning in silicon: A communications-inspired approach. In ICML Workshop on On-Device Intelligence. Available at https://arxiv.org/abs/1611.03109.

Shannon KL, Kim BF, McKenzie SE and Lawrence RS (2015) Food system policy, public health, and human rights in the United States. Annual Review of Public Health 36, 151-173. Available at http://dx.doi.org/10.1146/annurev-publhealth-031914122621.

Sharma K (n.d.) AI for Good is designed to apply AI to tackle some of the toughest humanitarian challenge. Available at https:// www.aiforgood.co.uk/ 26th July 2020.

Shehabi A, Smith SJ, Horner N, Azevedo I, Brown R., Koomey J, Masanet E, Sartor D, Herrlin M and Lintner W (2016) United States data center energy usage report. Technical Report LBNL-1005775, Lawrence Berkeley National Laboratory, Berkeley, California. Available at https://cda.iea-4e.org/document/46/united-states-data-center-energy-usage-report.

Simpson S (2011) Afghanistan holds enormous bounty of rare earths, mineral. Scientific American, 29 September 2011. Available at https://www.scientificamerican.com/article/afghanistan-holds-enormous-bounty-of-rare-earths/.

Singer K (n.d.) The campaign to reduce our internet footprint. In Our Web of Inconvenient Truths. The Internet, Energy Use, Toxic Waste and Climate Change. Available at https://www.ourwebofinconvenienttruths.com/campaign/26th July 2020.

Singh PJ and Vipra J (2019) Economic rights over data: A framework for community data ownership. Development 62, 53-57. Available at https://doi.org/10.1057/s41301-019-00212-5.

Song $\mathbf{L}$ and Zeng AP (2018) Orthogonal information encoding in living cells with high error-tolerance, safety, and fidelity. ACS Synthetic Biology 16, 866-874. Available at https://doi.org/10.1021/acssynbio.7b00382.

Stahl BC, Timmermans $\mathbf{J}$ and Flick C (2017) Ethics of emerging information and communication technologies: On the implementation of responsible research and innovation. Science and Public Policy 44, 369-381. Available at https://dx.doi. org/10.1093/scipol/scw069.

Stauffer NW (2013) Energy-efficient computing. Enabling smaller, lighter, faster computers. MIT Energy Initiative, 20 June 2013. Available at http://mitei.mit.edu/news/energy-efficient-computing.

Stefano GB, Wang F and Kream RM (2018) DNA MemoChip: Long-term and high capacity information storage and select retrieval. Medical Science Monitor 24, 1185-1187. Available at https://www.ncbi.nlm.nih.gov/pmc/articles/PMC5841191/.

Sterflinger K and Piñar G (2013) Microbial deterioration of cultural heritage and works of art-Tilting at windmills? Applied Microbiology and Biotechnology 97, 9637-9646. Available at http://dx.doi.org/10.1007/s00253-013-5283-1.

Stern DI (2011) The role of energy in economic growth. Annals of the New York Academy of Sciences 1219, 26-51. Available at https://doi.org/10.1111/j.1749-6632.2010.05921.x.

Stinchcombe K (2017) Ten years in, nobody has come up with a use for blockchain. Hacker Noon, 23 December 2017. Available at https://hackernoon.com/ten-years-in-nobody-has-come-up-with-a-use-case-for-blockchain-ee98c180100.

Stoica I, Song D, Popa RA, Patterson DA, Mahoney MW, Katz RH, Joseph AD, Jordan M, Hellerstein JM, Gonzalez J, Goldberg K, Ghodsi A, Culler DE and Abbeel P (2017) A Berkeley view of systems challenges for AI. Technical Report UCB/EECS-2017-159. EECS Department, University of California, Berkeley. Available at http://www2.eecs.berkeley.edu/ Pubs/TechRpts/2017/EECS-2017-159.html.

Stolton S (2020) Commission: Internet “under strain” amid COVID-19 overuse. Euractiv, 19 March 2020. Available at https:/ www.euractiv.com/section/digital/news/commission-internet-under-strain-amid-covid-19-overuse/.

Strubell E, Ganesh A and McCallum A (2019) Energy and policy considerations for deep learning in NLP. arXiv:1906.02243 [cs. CL]. Association for Computational Linguistics (ACL). Available at https://arxiv.org/abs/1906.02243.

Suárez-Torres J, Suárez-López JR, López-Paredes D, Morocho H, Cachiguango-Cachiguango LE and Dellai W (2017) Agroecology and health: Lessons from Indigenous populations. Current Environmental Health Reports 4, 244-251. Available at https://dx.doi.org/10.1007/s40572-017-0146-z. 
Sze V, Chen Y-H, Emer J, Suleiman A and Zhang Z (2017a) Hardware for machine learning: Challenges and opportunities. In IEEE Custom Integrated Circuits Conference (CICC), pp. 1-8. IEEE. Available at https://dx.doi.org/10.1109/ CICC.2017.7993626.

Sze V, Chen Y-H, Yang T-J and Emer J (2017b) Efficient processing of deep neural networks: A tutorial and survey. Proc IEEE 5, 2295-2329. Available at https://doi.org/10.1109/JPROC.2017.2761740.

Tavella F, Giaretta A, Dooley-Cullinane TM, Conti M, Coffey L and Balasubramaniam S (2018) DNA molecular storage system: Transferring digitally encoded information through bacterial nanonetworks. arXiv:1801.04774 [cs.ET]. Available at https://arxiv.org/abs/1801.04774.

Taylor S (2018) “Global health”: Meaning what? BMJ Global Health 3, e000843. Available at https://dx.doi.org/10.1136/bmjgh2018-000843.

Tekisalp L (2020) Beyond hype and innovation: AI for social good. Partnership on AI, 25 February 2020. Available at https:// www.partnershiponai.org/beyond-hype-and-innovation-ai-for-social-good/.

Thomas J (2019) An overview of emerging disruptive technologies and key issues. Development 62, 5-12. Available at https:// doi.org/10.1057/s41301-019-00226-z.

Torcellini P, Pless S, Deru M and Crawley D (2006) Zero energy buildings: A critical look at the definition. National Renewable Energy Laboratory and U.S. Department of Energy. Available at https://www.nrel.gov/docs/fy06osti/39833.pdf.

Torresen J (2018) A review of future and ethical perspectives of robotics and AI. Frontiers in Robotics AI 4, 75. Available at https:// doi.org/10.3389/frobt.2017.00075.

Trade and Development Board, Trade and Development Commission, and Intergovernmental Group of Experts on Competition Law and Policy (2019) Competition issues in the digital economy. Technical report. United Nations Conference on Trade and Development (UNCTAD). Available at https://unctad.org/meetings/en/SessionalDocuments/ciclpd54_en.pdf.

Turpin JR (2017) Cutting back on energy use in data centers. ACHR News, 6 February 2017. Available at http://www.achrnews. com/articles/134410-cutting-back-on-energy-use-in-data-centers.

Tymoigne E (2013) Bitcoin system: Some additional problems. New Economic Perspectives, 9 December 2013. Available at http:// neweconomicperspectives.org/2013/12/bitcoin-system-additional-problems.html.

UK Research and Innovation (UKRI) (n.d.) UKRI brings together the seven Research Councils, Innovate UK and Research England. Available at https://www.ukri.org/about-us/ 26 July 2020.

UK Research and Innovation (UKRI) (2020) UKRI launches its environmental sustainability strategy and sets a path to a "net zero" future. Available at https://www.ukri.org/news/ukri-launches-its-environmental-sustainability-strategy-and-sets-a-pathto-a-net-zero-future/.

United Nations Conference on Trade and Development (UNCTAD) (2019) Digital economy report 2019. Value creation and capture: Implications for developing countries. Technical report. United Nations. Available at https://unctad.org/en/Publication sLibrary/der2019_overview_en.pdf.

Villani C (n.d.) AI for Good. Unite to act. We put actors of the ecosystem at the service of a better world. Available at https:// www.aiforgood.eu/ 26th July 2020.

Villa-Serrano AM, Perez-Murcia MD, Perez-Espinosa A, Moreno-Caselles J, Gálvez-Sola M and Bustamante MA (2010) Characterization and agronomic use of pigeon manure: A case study in the northeast Transmontano region (Portugal). Available at https://www.researchgate.net/publication/335404839_CHARACTERIZATION_AND_AGRONOMIC_USE_OF_ PIGEON MANURE A CASE STUDY IN THE NORTHEAST TRANSMONTANO REGION PORTUGAL

Wall K (2017) The weekly package. How Cubans deliver culture without internet. Harper's Magazine. Available at https:// harpers.org/archive/2017/07/the-weekly-package/.

Walsh B (2013) The surprisingly large energy footprint of the digital economy. Time, 14 August 2013. Available at http:// science.time.com/2013/08/14/power-drain-the-digital-cloud-is-using-more-energy-than-you-think/.

Weber I, Gramoli V, Ponomarev A, Staples M, Holz R, Tran A and Rimba P (2017) On availability for blockchain-based systems. In IEEE Symposium on Reliable Distributed Systems (SRDS). Available at http://dx.doi.org/10.1109/SRDS.2017.15.

Wei S, Jiang Z, Liu H, Zhou D and Sanchez-Silva M (2014) Microbiologically induced deterioration of concrete-A review. Brazilian Journal of Microbiology 44, 1001-1007. Available at http://dx.doi.org/10.1590/S1517-83822014005000006.

Wikipedia contributors (n.d.) Zero-energy building. Wikipedia, The Free Encyclopedia. Available at https://en.wikipedia.org/ wiki/Zero-energy_building 26 July 2020.

Willett W, Rockström J, Loken B, Springmann M, Lang T, Vermeulen S, Garnett T, Tilman D, DeClerck F, Wood A, Jonell M, Clark M, Gordon LJ, Fanzo J, Hawkes C, Zurayk R, Rivera JA, De Vries W, Majele Sibanda L, Afshin A, Chaudhary A, Herrero M, Agustina R, Branca F, Lartey A, Fan S, Crona B, Fox E, Bignet V, Troell M, Lindahl T, Singh S, Cornell SE, Srinath Reddy K, Narain S, Nishtar S and Murray CJL (2019) Food in the anthropocene: The EAT-Lancet Commission on healthy diets from sustainable food systems. The Lancet 393, 447-492. Available at https://dx.doi.org/10.1016/S0140-6736(18) 31788-4.

Winner L (1980) Do artifacts have politics? Daedalus 109, 121-136. Available at https://www.jstor.org/stable/20024652.

Wintle BC, Boehm CR, Rhodes C, Molloy JC, Millett P, Adam L, Breitling R, Carlson R, Casagrande R, Dando M, Doubleday R, Drexler E, Edwards B, Ellis T, Evans NG, Hammond R, Haseloff J, Kahl L, Kuiken T, Lichman BR, Matthewman CA, Napier JA, ÓhÉigeartaigh SS, Patron NJ, Perello E, Shapira P, Tait J, Takano E and Sutherland WJ (2017) A transatlantic perspective on 20 emerging issues in biological engineering. eLife 6, e30247. Available at https://doi.org/ 10.7554/eLife.30247. 
World Economic Forum (2017) Shaping the future of digital economy and society. Available at https://www.weforum.org/systeminitiatives/shaping-the-future-of-digital-economy-and-society.

Wright J (2012) How agroecology can support food security. Huffington Post, 16 May 2012. Available at https://www. huffingtonpost.co.uk/dr-julia-wright/how-agroecology-can-suppo_b_1520229.html.

Yachie N, Ohashi Y and Tomita M (2008) Stabilizing synthetic data in the DNA of living organisms. Systems and Synthetic Biology 22, 19-25. Available at https://doi.org/10.1007/s11693-008-9020-5.

Zehner O (2012) Green Illusions: The Dirty Secrets of Clean Energy and the Future of Environmentalism. Lincoln, NE: University of Nebraska Press. Available at http://www.nebraskapress.unl.edu/product/Green-Illusions,675003.aspx.

Zero Waste International Alliance (n.d.) Working towards a world without waste. Available at http://zwia.org 26 July 2020.

Zhang K, Schnoor JL and Zeng EY (2012) E-waste recycling: Where does it go from here? Environmental Science \& Technology 46, 10861-10867. Available at http://dx.doi.org/10.1021/es303166s.

Zhang Q, Wu J, Sun Y, Zhang M, Mai B, Mo L, Lee TM and Zou F (2015) Do bird assemblages predict susceptibility by e-waste pollution? A comparative study based on species- and guild-dependent responses in China agroecosystems. PLoS One 10, e0122264. Available at https://doi.org/10.1371/journal.pone.0122264.

Zink T and Geyer R (2017) Circular economy rebound. Journal of Industrial Ecology 21, 593-602. Available at https://dx.doi.org/ 10.1111/jiec.12545.

Cite this article: Mian, I. S. Twisleton, D. and Timm, D. A. 2020. What is the resource footprint of a computer science department? Place, people, and Pedagogy. Data \& Policy, 2: e14. doi:10.1017/dap.2020.12 